\title{
ERUPTIVE AND STRUCTURAL HISTORY OF TEIDE VOLCANO AND RIFT ZONES OF TENERIFE, CANARY ISLANDS
}

\author{
J. C. Carracedo ${ }^{*}$, E. Rodríguez Badiola ${ }^{2}$, H. Guillou ${ }^{3}$, M. Paterne ${ }^{3}$, S. Scaillet ${ }^{3}$, \\ F. J. Pérez Torrado ${ }^{4}$, R. Paris ${ }^{5}$, U. Fra-Paleo ${ }^{6}$ and A. Hansen ${ }^{4}$
}

${ }^{\text {I} E s t a c i o ́ n ~ V o l c a n o l o ́ g i c a ~ d e ~ C a n a r i a s, ~ C S I C, ~ L a ~ L a g u n a, ~ T e n e r i f e, ~ S P A I N ~}$

${ }^{2}$ Museo Nacional de Ciencias Naturales, CSIC, 28006 Madrid, SPAIN

${ }^{3}$ Laboratoire des Sciences du Climat et de l'Environnement, CEA-CNRS, FRANCE

${ }^{4}$ Dpto. Física-Geología, ULPGC, 35017 Las Palmas de Gran Canaria, SPAIN

${ }^{5}$ Géolab UMR 6042 CNRS, Maison de la Recherche, Clermont-Ferrand, FRANCE

${ }^{6}$ Depto. Geografía y Ordenación del Territorio, Universidad de Extremadura, SPAIN

* Corresponding author: mailto:jcarracedo@ipna.csic.es

Keywords: radioisotopic ages, volcanic history, structural history, rift volcanism, nested central volcanoes, Teide Volcano, Tenerife, Canary Islands.

\begin{abstract}
The Teide and Pico Viejo stratocones and the NW and NE Rifts are products of the latest eruptive phase of the Island of Tenerife, initiated with the lateral collapse of its northern flank that formed the Cañadas Caldera and the Icod-La Guancha Valley at about $200 \mathrm{ka}$. The eruptive and structural evolution of this volcanic complex has been reconstructed after detailed geological mapping and radioisotopic dating of the significant eruptive events. A set of 54 new ${ }^{14} \mathrm{C}$ and $\mathrm{K} / \mathrm{Ar}$ ages provides precise age control of the recent eruptive history of Tenerife, particularly Teide Volcano, the third highest volcanic feature on earth (3718 $\mathrm{m}$ a.s.1., $>7 \mathrm{~km}$ high) and quite unique in terms of its intraplate setting. The development of the Teide-Pico Viejo volcanoes may be related to the activity of the NW and NE Rifts. Volcanic and intrusive activity along both rift zones may have played an important role in activating the gravitational landslide and in the subsequent growth, nested within the collapse embayment, of an increasingly higher central volcano with progressively differentiated magmas. The coeval growth of the central volcano with sustained activity
\end{abstract}


along the rifts led to a clear bimodal distribution in composition of eruptive products, with the basaltic eruptions in the distal part of the rifts and phonolitic and more explosive eruptions in the central area, where the differentiated stratocones developed. Current volcanic hazard in Tenerife is considered to be moderate, because eruptive frequency is low, explosivity is modest, and the eruptive activity of the Teide stratocone seems to have declined over the last $30 \mathrm{k} . \mathrm{y}$, with only one eruption in this period (1150 cal yr BP).

\section{INTRODUCTION}

Study of the most recent period of eruptive activity in the Canary Islands was almost completely neglected until a few years ago. The majority of the Late Pliocene-Holocene volcanism, which occurred on the juvenile islands of La Palma and El Hierro, and during the latest phase of eruptive activity of Tenerife, was poorly understood, principally because of the dearth of accurate radioisotopic dating of eruptive events and the precise mapping and reconstruction of these eruptions. This situation improved considerably for La Palma and El Hierro after work by Ancochea et al. (1994), Carracedo et al. (1999a,b; 2001) and Guillou et al. $(1996,1998,2001)$. We present here the results for the most recent phase (200 ka to present) of eruptive activity of Tenerife, which are critical in evaluations of hazards posed by possible renewed activity. The correct assessment of eruptive hazards is especially important for the Canaries and particularly for Tenerife (1 million inhabitants, 4.5 million annual visitors), which has relatively frequent Holocene phonolitic eruptions with explosivity higher than for more typical basaltic fissure eruptions.

A proper hazard assessment can only be attained through detailed reconstruction of the recent eruptive record. Precise and comprehensive radioisotopic dating and detailed characterization of the successive eruptions are critically important. Otherwise, speculative statements from poorly constrained interpretations may lead to overstating the actual volcano hazards, thereby causing unnecessary false alarms and distress among the population and economic loss from decreased tourism. These concerns, in turn, also hinder the means to provide correct and reliable scientific support to the authorities in the event of a true eruptive crisis.

Although Mt. Teide has been one of the European Laboratory Volcanoes (ESF European Volcanological Project-EVOP) and a Decade Volcano of the UN International Decade (1990s) for Natural Disaster Reduction (IDNDR), the greater part of the research was focused on the older ( $>200 \mathrm{ka})$ pre-caldera Las Cañadas Volcano. Meanwhile, only limited progress was made on the reconstruction of the latest (post-caldera) eruptive history of Tenerife, mainly restricted to a revision of the early work and mapping of Navarro (1980), although considerably improved in the petrological and geochemical aspects (Ablay et al., 1998; Ablay and Martí, 2000). Particularly deficient and surprising was the almost total lack of geochronological 
information, restricted to a single age for the Mña. Blanca lava dome at the base of Teide (Ablay et al., 1995), scant historical records comprising a few eruptions during the last 500 years, and some vague references to possible activity by passing navigators.

Several authors (Araña et al., 2000) stated that a more precise reconstruction of the recent eruptive period of Tenerife (the Teide Volcano and the NW and NE rift zones) was unfeasible, because of the impossibility of applying $\mathrm{K} / \mathrm{Ar}$ and ${ }^{40} \mathrm{Ar} /{ }^{39} \mathrm{Ar}$ techniques to this period and the absence of suitable organic material (charcoal) for radiocarbon dating. This assertion has proved to be wrong; we have collected 58 samples of charcoal, 28 of which have been dated. Furthermore, our work on other islands of the Canarian Archipelago demonstrated the value of unspiked K-Ar analyses for dating recent Quaternary events (Guillou et al., 1996, 1998, 2004b). As a consequence, the oldest formations (200-30 ka), comprising the coastal cliffs and the lower part of the volcanic sequence filling the Icod-La Guancha Valley, accessible through water tunnels (galerias) that mine deep into the volcano, were dated by the unspiked K/Ar method, and the recent volcanics $(<30 \mathrm{ka})$ with radiocarbon techniques.

The reconstruction of the volcanic and structural evolution of the Teide volcanic complex and the NW and NE rift zones presented in this work has been achieved after detailed (1:10,000) geological (GIS) mapping and radioisotopic dating of the significant eruptive events. The preparation and examination of more than 500 thin sections of lavas, 100 of them analyzed for major and trace elements, were crucial in the definition and mapping of the successive eruptions, leading to a comprehensive understanding of the petrological evolution of the entire volcanic system. These new petrological and geochemical studies will be published separately.

An important part of this work included the study and correlation -using the numerous tunnels (galerias) excavated for groundwater exploitation- of the volcanic formations corresponding to the early phases of filling of the Las Cañadas collapse embayment and the older rift eruptions (pre- and postcollapse) capped at present by the younger eruptive products.

\section{GEOLOGICAL BACKGROUND}

The Canarian Archipelago is made up of seven islands that represent different stages of geologic evolution (Schmincke, 1979; Carracedo, 1999; Carracedo et al., 1998, 2001, 2002). Tenerife, the central island of the archipelago, is currently at the zenith of its volcanic development (Guillou et al., 2004a). In contrast, the more westerly islands are still in the shield-stage and have not reached the same level of development. The post-erosional eastern islands have already passed that point and are now in an advanced stage of erosion. Tenerife has developed the complex formed by the rifts and the Teide-Pico 
Viejo stratovolcanoes (Fig. 1), comprising a unique and extraordinary volcanic system marking the highest altitude of the island and the archipelago. This volcanic complex is the only one of this type that currently exists in the Canary Islands in this state of preservation, either because similar systems have not yet been formed -as in the western islands- or because they have already disappeared because of erosion in the eastern islands, as in the case of the Roque Nublo in Gran Canaria, a volcano once similar to Teide that has already been dismantled (Pérez Torrado, 2000).

The significant geological differences between the Canary Islands and the majority of other intraplate oceanic islands can be explained by the unique geodynamic setting in which the Canary Islands originated and developed (Schmincke, 1979, 1982; Carracedo et al., 1998, 2002). Indeed, the vast majority of intraplate oceanic volcanic islands formed over flexible oceanic crust, and are associated with faster-moving lithospheric plates and much more vigorous mantle thermal plumes. This geological scenario favors rapid island formation, with high effusion rates, generating magmas that are uniform in composition, generally corresponding to the initial phases of the ocean island basalt (OIB) magmatic series (Walker, 1990; Clague, 1987; Tilling et al., 1989). These magmas can evolve to more differentiated products in large quantities (trachybasalts, phonolites, trachytes), although this requires the magma to remain in reservoirs for long periods. However, most intraplate oceanic islands are usually re-submerged by subsidence before important volumes of differentiated magmas can be produced (Walker, 1990; Tilling et al., 1989). In the prototypical Hawaiian Archipelago, only those islands younger than 6 million years (from Hawaii to Kauai) remain emergent, and differentiated lavas are of minor significance, at least compared to the Island of Tenerife.

Conversely, the Canary Islands, which are located over very old crust and near a passive continental margin, present a quite different geological scenario, where subsidence processes are not significant and the islands remain above sea level for long periods of time (e.g., more than 23 million years in the case of Fuerteventura), possibly until substantial erosion down to sea level (Carracedo, 1999; Carracedo et al., 1998, 2002). Moreover, the very long magmatic history of the Canary Islands provides favorable conditions for the differentiation of large volumes of magma (Klügel et al., 1997, 1999; Nelson et al., 2005), leading to processes that account for the presence of unique geological features on the Island of Tenerife, in particular, large-volume differentiated central volcanoes.

As shown in Figure 1, the Island of Tenerife, like the other Canarian islands and intraplate oceanic islands in general, was built by coalescence of three large shield volcanoes (Fúster et al., 1968; Carracedo, 1979; Ancochea et al., 1990; Thirlwall et al., 2000; Guillou et al., 2004a). Each individual shield was apparently constructed in less than 3 million years, and the entire island in about 8 million years (Guillou et al., 2004a). This shield-stage volcanism formed the bulk of the subaerial part of Tenerife between about 
12 and 4 million years ago.

A significant part of the total mass of Tenerife at this stage (1000-2000 $\mathrm{km}^{3}$ subaerial mass and another submarine $10,000-20,000 \mathrm{~km}^{3}$ ) was probably mass-wasted by recurrent giant gravitational landslides, particularly on the north flank of the Central shield. Although this Miocene volcano is now almost completely covered by products of subsequent eruptions except for the southern outcrop of the Roque del Conde massif (Fig. 1), its continuation and geometry in the central part and northern and eastern flanks of the island can be observed in the numerous galerias that have been excavated for groundwater exploitation (Coello, 1973; Carracedo, 1979; Guillou et al., 2004a).

The shield-building stage was followed by a period of 2-3 million years of quiescence and erosion, typical for these islands (La Gomera is currently in this erosional stage, Paris et al., 2005). Volcanic eruptions then resumed during the second and concluding stage of volcanic rejuvenation of the island, during which the large central volcano of Las Cañadas - the main volume of this stage in Tenerife- developed unconformably over the central Miocene shield, probably reaching $40 \mathrm{~km}$ in diameter and a height of 2700-3000 m. Details of this stage of evolution can be found in Ancochea et al. (1990, 1999) and Martí et al. (1994).

Around $200 \mathrm{ka}$, the summit of Las Cañadas Volcano collapsed to create the Las Cañadas Caldera depression, while the ensuing volcanism comprises the most recent volcanic phase of Tenerife. The genesis of the Las Cañadas depression, which extends toward the northern coast forming the Icod-La Guancha Valley, is still controversial. Two models have been proposed: 1) A vertical collapse associated with emptying of a shallow magma chamber following large-volume explosive eruptions (Martí et al., 1994, 1997; Martí and Gudmundsson, 2000), and 2) Lateral gravitational collapses, similar to those first described for Hawaii (Moore, 1964) and documented in the Canaries by onshore observations (Carracedo, 1994, 1999; Guillou et al., 1996; Carracedo et al., 1998, 2001, 2002; Stillman, 1999) and marine geology studies (Watts and Masson, 1995; Urgelés et al., 1997, 1999; Masson et al., 2002).

New radioisotopic ages and detailed observations on the two main volcanological structures of this latest eruptive phase of Tenerife - the NW and NE rift zones and the main stratocones- shed new light on this controversy. They support the crucial role of the rifts in generating a complex sequence of processes: the development of a steep-sloped and unstable central volcano (the Las Cañadas Volcano); its partial mass-wasting triggered by massive sector collapse; filling of the resulting embayment with progressively differentiated lavas; and, finally, the development of the Teide and Pico Viejo stratocones nested within the embayment. 


\section{GEOCHRONOLOGY}

The almost total lack of radiometric ages prior to this work for the Teide volcanic complex is quite remarkable, and this dearth of age control is particularly limiting when attempting the reconstructing of the recent eruptive history of Tenerife, one of the most densely populated, volcanically active ocean islands. Moreover, Teide Volcano, the third highest volcanic feature on the planet and an unusually extensively differentiated central volcano, is quite unique in terms of intraplate geological settings. The utility of extensive radiocarbon dating in the detailed reconstruction of the most recent (last $38 \mathrm{ka}$ ) eruptive activity has been well demonstrated for the Island of Hawaii (Lockwood, 1995; Rubin et al., 1987). Without the constraints of radiometric ages, the detailed mapping and the definition of the individual eruptive units of the Teide and rift zones volcanic complex would be very difficult, because of the homogeneous nature of the recent lavas (many of them aphanitic and with very similar morphological features) and the lack of other useful criteria for their characterization.

During our work, the reliability of unspiked K/Ar dating for recent lavas ( $<30 \mathrm{ka})$, successfully used for dating the western Canaries (Guillou et al., 1996, 2001, 2004a,b), was confirmed. In addition, we have found abundant organic material (charcoal). Charcoal is generally absent in basaltic and intermediate $a a$ type flows due to the high temperature of the lavas and the amount of loose basal scorias favoring the presence of abundant oxygen and thus complete combustion of wood. The samples of charcoal we collected were consistently related to large partially burnt tree trunks, carried to the margins of the flowing lavas. Most of the charcoal samples were collected from the Pico Viejo lavas and thick phonolitic flows from the Teide stratocone and its peripheral lava domes, and from basaltic and intermediate composition flows from fissure eruptions of the NW and NE rifts. Charcoal remnants were also abundant inside airfall pumice deposits; however, many of these charcoal fragments were related to forest fires of uncertain ages; some of them were clearly modern (0 age).

\section{Radiocarbon dating: Field and laboratory methods}

Stringent criteria were used to identify the charcoal residues suitable for reliable radiocarbon dating. Only charcoals clearly lying underneath lava flows were sampled with the assumption that the overlying lava or previous forest fires generated the charcoal residues, giving a maximum age in the latter case for the eruptive event. During this work, 58 samples of charcoal from the Teide-Pico Viejo stratocones and the NW and NE rift-zone lavas were collected, and 28 of the best ones were dated (Fig. 2), 21 of them in the Laboratoire des Sciences du Climat et de l'Environnement, CEA-CNRS (France), and the remaining 7 by Beta Analytic Radiocarbon Dating Laboratory (USA. The conversion of ${ }^{14} \mathrm{C}$ conventional ages into 
calendar-calibrated ages (CAL yr BP) was obtained by means of the INTCAL04 Terrestrial Radiocarbon Age Calibration (Reimer et al., 2004).

\section{Results}

The sample locations and results of the dating are given in Figure 2 and Table 1; all ages discussed in the text are 2-sigma calibrated years BP.

Useful radiocarbon ages were difficult to obtain for samples from the NE Rift. Two of the samples analyzed (TFC-153 and TFC-170 in Fig. 2 and Table 1) were too old for the method ( $>33 \mathrm{ka}$ ). Two samples (not listed in Table 1) have 0 age. Sample TFC-172 (Table 1), with an age of 590 \pm 66 cal yrs BP, is incompatible with the stratigraphy. The only eruption dated by this method in the NE Rift is the Volcán del Portillo (TFC-178 and TFC-176, Table 1), which yielded two different ages of 13,005 \pm 132 and 13,889 \pm 163 cal yr BP. Determinable radiocarbon ages in the NW Rift are more abundant (Table 1) and vary from $15,140 \pm 230$ cal yr BP, corresponding to the oldest eruption dated (Mña. del Banco, on the western edge of the rift), to the age of the young Boca Cangrejo eruption, dated at $400 \pm 110 \mathrm{cal}$ yr BP.

Pico Viejo and Teide stratovolcanoes were more difficult to date by radiocarbon techniques, because of the older ages of these formations and less abundant charcoal samples. Nonetheless, radiocarbon ages have been obtained for the main outcrops of the formations and eruptive phases of these volcanoes (Table 1). An interesting feature is the good correlation of the radiocarbon $(32,369 \pm 800 \mathrm{BP})$ and $\mathrm{K} / \mathrm{Ar}$ ages $(32 \pm 1$ $\mathrm{ka}$ and $33 \pm 2 \mathrm{ka}$ ) of the analyzed lavas of the Teide Volcano, all of them around $30 \mathrm{ka}$, as discussed below. A period of quiescence of about 30 k.y. separates the late eruptions of the Old Teide volcano from the most recent, prehistoric eruption (the Lavas Negras, $1150 \pm 140$ cal yr BP, or 660 to 940 AD calibrated age). The three Pico Viejo samples dated the three main constructive phases of this volcano, also determined by field observations: an initial phase of predominant pahoehoe lavas, dated at 27,030 $\pm 430 \mathrm{yr} \mathrm{BP}$; an intermediate phase of more evolved eruptions, dated at 20,775 $\pm 321 \mathrm{yr} \mathrm{BP}$; and a final phase of predominantly phonolitic events, dated at $17,525 \pm 365$ cal yr BP.

Charcoal was obtained from many of the phonolitic lava domes emplaced in the basal perimeter of the Teide and Pico Viejo stratocones (Table 1), yielding ages from $9210 \pm 190$ cal yr BP to $1714 \pm 151 \mathrm{cal}$ yr BP, the former corresponding to the Bocas de Doña María vent and the latter to the prominent Roques Blancos lava dome located on the western flank of Pico Viejo. No charcoal from the Pico Cabras lava dome was found, but according to its relative stratigraphic position, this eruption took place between the Bocas de Doña María and Abejera Alta eruptions (between about 9210 and 5911 cal yr BP). 


\section{K/Ar dating: Field and laboratory methods}

A set of 26 samples (Fig. 2 and Table 2) were collected for K/Ar dating of the eruptive products from the Teide Volcano and the rifts older than about $30 \mathrm{ka}$, beyond the limit of accurate applicability of radiocarbon dating. As mentioned earlier, lavas older than about $30 \mathrm{ka}$ correspond to the pre-collapse and early post-collapse activity of the rifts and to the initial and intermediate phases of filling of the collapse embayment. The former units only crop out along the coastal cliffs and inside galerías excavated in the IcodLa Guancha Valley, some of them cutting the entire formation and reaching the collapse debris avalanche deposits.

According to Guillou et al. (1996, 1998), the precision and accuracy of these ages have been greatly improved by: 1) using an unspiked K-Ar technique described in detail by Charbit et al. (1998), Scaillet and Guillou (2004) and appendix, especially devoted to dating Holocene and Upper Pleistocene volcanic samples; 2) dating the microcrystalline groundmass to reduce significantly the systematic errors due to excess ${ }^{40} \mathrm{Ar}^{*}$ (the sample preparation procedure is detailed in Guillou et al., 2004b); 3) collecting samples in well-controlled stratigraphic sequences to assess the geological significance of the obtained ages; and 4) comparing, when possible, with other dating methods: ${ }^{14} \mathrm{C}$ method (Guillou et al., 1996 and this paper) and ${ }^{40} \mathrm{Ar} /{ }^{39} \mathrm{Ar}$ method (Guillou et al., 2004c). This procedure has yielded reliable ages, consistent with stratigraphy and field observations, in the younger volcanics of the western Canaries (Guillou et al., 1996, 1998, 2001).

\section{Results}

Ages of samples from the NE Rift range from $8 \pm 4$ to $789 \pm 17 \mathrm{ka}$ (Table 2). The older ages correspond to the distal and early phases in the development of this rift that crop out in the northern coastal cliffs east of the Orotava Valley and in the SE coast. The eruptive centers at the proximal end of this rift (near the rim of Las Cañadas caldera) show consistent ages of 31 to $37 \mathrm{ka}$, equivalent to the period of completion of the growth of the Teide stratovolcano.

The ages of the distal part of the NW Rift range from $153 \pm 6$ to $1153 \pm 25$ ka (Table 2). The older ages correspond to the early phases in the development of this rift that crop out in the northern wall of the IcodLa Guancha Valley and in the SW coast, near Puerto de Santiago (see Fig. 3).

Rift eruptions prior and subsequent to the formation of the Las Cañadas Caldera and the Icod-La Guancha Valley may be relatively common, because apparently the rifts have been active throughout the construction of the Las Cañadas Volcano, as evidenced by the ages obtained (Table 2) and the overlapping basaltic fissure eruptions in the area of the rifts with the more felsic (phonolitic) and explosive volcanism 
of Las Cañadas Volcano (Martí et al., 1994). Eruptions continued during the Holocene in the NW and NE rift zones, but not in the Southern Rift, where one of the youngest eruptions (La Buzanada) has been dated at $96 \pm 5 \mathrm{ka}$ (Table 2).

The Old Teide lavas were sampled from one of the phonolitic eruptions that buried the Las Cañadas Caldera floor and spilled over into the Orotava Valley. This gave an age of $33 \pm 2 \mathrm{ka}$ (CITF-98, Table 2), consistent with the radiocarbon age for the same flow (TFC 167, Table 1). Another phonolitic flow (CITF301) reaching the coast at Playa de San Marcos gave a similar K/Ar age of $32 \pm 1$ ka (Table 2). This external check reinforces the geological significance of the K/Ar ages. Older lavas sampled lower in the cliffs along the northern coast gave ages of $88 \pm 4$ and $124 \pm 4$ ka (Table 2).

The best information on the age of the early phases filling the collapse embayment was obtained in the galería Salto del Frontón, a $4555 \mathrm{~m}$-long tunnel located at an altitude of $800 \mathrm{~m}$ in the Icod-La Guancha Valley (Fig. 4 and Table 2). The older lavas (basalts, basanites) suitable for dating gave an age of $198 \pm 5$ ka (10 GSF, 2700 m, Figure 4 and Table 2). Younger and more evolved lavas (plagioclase basalts, phonotephrites) at 1500 and $1100 \mathrm{~m}$, respectively, gave ages of $110 \pm 4$ and $118 \pm 3 \mathrm{ka}$, equivalent in age to the formations cropping out along the coastal cliffs.

\section{DISCUSSION}

\section{Geochronology and volcanic history of the main volcanic units}

The new radioisotopic ages and detailed stratigraphic and structural observations allow the reconstruction of the volcanic history of the rifts and the central volcanic system. To facilitate discussion, five main volcanic units have been distinguished in the latest eruptive phase of Tenerife (Fig. 3): 1. The NE Rift, 2. The NW Rift, 3. The Teide volcano, 4. The Pico Viejo volcano, and 5. The parasitic, peripheral lava domes. However, this grouping is more geographical than volcanological because, as discussed in detail in the section on structural evolution, the distinctions between main units based on volcanological considerations alone may not be diagnostic since the entire volcanic set -the rifts and the central volcanoes- act as an essentially continuous, interconnected system. Nonetheless, the distinction (compositional, source of eruption) between basaltic rift eruptions and the phonolitic eruptions of the central volcanoes is unambiguous, because these units represent the extremes of the bimodal compositional system. However, this distinction is less evident in the middle, transitional part of the rifts where lava composition changes gradually. It is problematic whether Mña. Blanca should be considered to be related to the proximal activity of the NE Rift, or as an adventive dome of the Teide volcano. The same issue arises with Pico Viejo volcano, which may represent an enlarged polygenetic parasitic vent of Teide volcano at the eastern end of the NW rift zone. 


\section{The NE Rift Zone}

The NE Rift extends from the base of the Teide stratovolcano toward the NE of the island, overlying the western flank of the Anaga Mio-Pliocene shield volcano (Walter et al., 2005). The age of this rift zone extends back at least to the Middle Pleistocene (Table 2), interacting with the development of the Las Cañadas Volcano. According to Cantagrel et al. (1999), Martí et al. (1994) and Huertas et al. (2002), basaltic fissure eruptions, with the eruptive centers aligned in a similar pattern to the present NE rift zone, alternate with differentiated eruptions of the central Las Cañadas Volcano.

Near the Las Cañadas Caldera, the NE Rift comprises a cluster of basaltic vents (Mña. Guamasa, Mña. de Enmedio, Mña. Cerrillar) formed from 31 to $37 \mathrm{ka}$, feeding flows that extend down both flanks of the ridge into the Orotava Valley and toward the SE flank of the island (Table 2 and Figs. 3 and 5). The volcanic alignment ends abruptly at the rim of the caldera, implying that here the western part of the rift was completely removed by the collapse. The post-collapse intracaldera part of the rift is, accordingly, formed by younger eruptions. Basaltic vents (Mña. Mostaza and Mña. Arenas Negras, 9 and 10 in Fig. 5) form the distal part of the intracaldera rift, with ages constrained between the underlying Old Teide phonolites

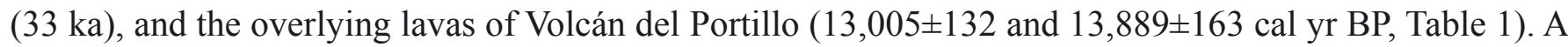
concordant ${ }^{3} \mathrm{He} /{ }^{4} \mathrm{He}$ exposure age of 15 ka for Mña. Mostaza is quoted in Ablay and Martí (2000).

Erupted lavas trend to younger and intermediate compositions toward the central part of the caldera, from Volcán del Portillo (13 ka) to Mña. de los Conejos and Mña. de los Corrales eruptions, with a maximum age provided by the underlying $9210 \pm 190$ cal yr BP eruption of Bocas de Doña María (Table 1), and a minimum age constrained by the Mña. Blanca volcano, dated at about 2 ka (Ablay et al., 1995). The proximal end of the rift, close to the base of the Teide stratovolcano, is formed by a group of differentiated (phonolitic) eruptive vents (Mña. Majúa, Mña. de la Cruz) capped by a polygenetic edifice (Mña. Blanca volcano), formed by at least 7 overlapping phonolitic eruptions, clustered around 2 ka (Fig. 5). The most recent activity of this rift comprises the historical (1704-1705) eruptions of Siete Fuentes, Fasnia and Arafo, located outside the caldera and at the southern edge of the rift zone (Figs. 3 and 5).

Notable features of this rift are: 1) the distinct bimodal distribution of flow compositions, with the felsic (phonolitic) eruptions located at the proximal end of the rift and the mafic eruptive vents along the distal part, close to the caldera scarp; 2) the increase in eruptive rate and frequency of eruptions toward the central volcanoes, where the rifts merge and the fracturing is more dense; and 3) the relatively intense and frequent Holocene eruptive activity, entirely located inside the caldera with the sole exception of the small historical eruptions. 
Lava flows from the intracaldera activity of the rift accumulated almost entirely within the depression. The only exceptions are the Volcán del Portillo, whose vents are located precisely at the part of the caldera rim breached by retrogressive erosion of the headwall of the Orotava Valley, and lavas from the Mña. de los Conejos eruption (6 in Fig. 5A) that overflow this opening, forming a short lava tongue perched at the head of the valley.

\section{The NW Rift Zone}

The older eruptions of the NW Rift were either removed in the lateral collapse or buried during the last 30 k.y. by the Pico Viejo lavas or more recent eruptive products. Consequently, older volcanics from this structure can only be observed inside galerías or in the distal part of the rift as eruptive vents and lava flows that cap the Miocene Teno massif (Fig. 6). An inspection of the deeper formations of this rift showed that the entire sequence forms a relatively thin layer capping the western flank of Las Cañadas Volcano, and a few eruptive vents (Mña. del Palmar and Volcán de Teno Alto, 27 and 30 in Fig. 6A) at the most distal westernmost edge of the Teno massif. Several other vents (Mña. de Los Silos and Mña. de Taco, 28 and 29 in Fig. 6A) are exposed on the northern coastal wave-cut platform of the Miocene Teno massif.

The relatively low eruptive rate of this rift zone (and the NE Rift also) is consistent with the posterosional stage of Tenerife. This rejuvenated volcanism shows eruptive rates and frequencies considerably lower than those of the main-stage rifts of the islands of La Palma and El Hierro, still in the shield-building stage. Nevertheless, the NW Rift is the locus of most of the eruptive events of Tenerife during the last 15 k.y.

The NW Rift repeats the pattern described in the NE Rift: The older and more primitive (basanitic, basaltic) eruptions tend to focus at the distal part of the structure, whereas intermediate and phonolitic eruptions predominate in the central and proximal areas of the rift, providing distinct evidence for magma mixing (Araña et al., 1989; Rodríguez Badiola et al., 2006). With exception of the historical eruption of Chahorra Volcano (1798), the remaining eruptions are located outside the caldera, and their lavas flowed toward the coast down both flanks of the rift (Fig. 6A). Consequently, the western part of the Las Cañadas Caldera has not been filled with lavas, except those already mentioned, since about $17 \mathrm{ka}$, the last important period of growth of Pico Viejo volcano.

Eruptive vents at the extension of the NW rift into the Teno massif are considerably older than those at the central part of the NW rift and near the central stratovolcanoes, where the younger eruptions cap the preceding volcanism (cross-section in Fig. 6B). The few eruptive centers located in the Miocene Teno massif are consistently older than 150 ka (Table 2 and Fig. 6), whereas at the central part of the rift, at the 
edge of the Teno massif, the older observable eruptions are those of Mña. del Topo (25 in Fig. 6A) and Mña.

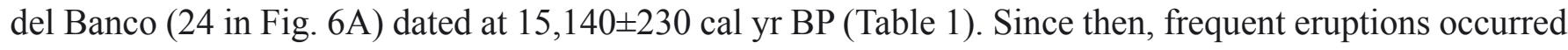
along this rift during the entire Holocene, including 4 historical eruptions (1-4 in Fig. 6A): Boca Cangrejo (1492), Chahorra (1798), Garachico (1706) and Chinyero (1909).

The eruption of Mña. Reventada (5 in Fig. 6A) shows interesting examples of magma mixing within a single lava unit. This eruption emitted flows containing mingled basaltic and phonolitic lavas, complicating the geological mapping. Apparently, a phonolitic flow "continued" as a basaltic flow when the more viscous phonolitic part of the lava unit stopped but the hotter, more fluid basaltic component continued to flow (Rodríguez Badiola et al., 2006).

The eruptions of the NW Rift form two distinct volcanic chains, the Chío and the Garachico volcanic chains, with a saddle between them (Fig. 6A). This feature is crucial in the control of flow directions; the lava flows from vents in the Chío chain consistently spread down the southern flank of the rift, while those in the Garachico chain flowed down the northern flank, and those located between both structures flowed along the saddle in a SE-NW direction (e.g., Mña. Reventada, Chinyero, etc.).

\section{The Teide stratovolcano}

Although Teide Volcano is geographically well defined as a stratovolcano resting on the floor of the Las Cañadas Caldera, the geological expression of the volcano, however, is not clear in spatial, temporal, or compositional terms. The initial growth of Teide Volcano is related to the earliest lavas filling the lateral collapse embayment that forms the horseshoe-shaped Icod-La Guancha Valley (Fig. 4A). This lava sequence is crossed entirely in the galería Salto del Frontón (Fig. 4B and 4C). From about 3450 m until the contact with the debris avalanche deposit, the rocks, saturated in water and at an ambient temperature above $35^{\circ} \mathrm{C}$, are moderately altered. All the analyzed samples from this area have high water contents (LOI $>1.5 \%$ ). These altered rocks, with olivine crystals partially oxidized and transformed into iddingsite and with vesicles filled with carbonates, proved unsuitable for dating. Consequently, the minimum age obtained for this section is $198 \pm 5 \mathrm{ka}$.

This age of $198 \pm 5 \mathrm{ka}(10 \mathrm{GSF}$, Fig. 4 and Table 2$)$ is equivalent to the age of an explosive deposit with syenite fragments capping the caldera wall, but not observed inside the collapse embayment. The ages obtained for this level give between 173 and $176 \mathrm{ka}$ with the K/Ar method (Mitjavila, 1990) and between $179 \pm 18$ and $183 \pm 8 \mathrm{ka}$ with the ${ }^{40} \mathrm{Ar} /{ }^{39} \mathrm{Ar}$ method (Mitjavila and Vila, 1993). This deposit was interpreted as related to the lateral collapse that formed the Las Cañadas Caldera (Ancochea et al., 1999).

As depicted in the cross section of the galería Salto del Frontón (Fig. 4C), the earliest lavas, which are 
basanitic, rest on debris avalanche deposits that originated from the collapse. Large volumes of basanite were erupted after depressurization that immediately followed the lateral collapse. K/Ar ages obtained for this section, together with the ages obtained from units of a similar stratigraphic position forming cliffs at the northern coast, show that a sequence of about $350 \mathrm{~m}$ of basanitic and basaltic lavas accumulated inside the embayment during a period of about $50 \mathrm{k.y}$. (Table 3), with higher accumulation rates at the junction of the rifts.

At the end of this eruptive phase a central volcano probably formed. Consequently, increasing edifice elevation and residence time of lavas in an initial shallow reservoir enabled the differentiation of magmas by fractional crystallization. This process continued for probably another 70-120 k.y., with eruptions of intermediate composition. Further differentiation of magmas within a shallow phonolitic magmatic chamber later fed the phonolitic eruptions of Teide. The development of the stratovolcano was completed at about 30 ka (Old Teide in Fig. 4B). Since then, Teide had only one eruption, which formed the summit crater and the

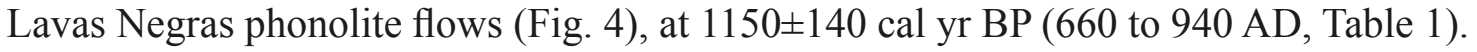

The early lava flows were restricted to the interior of the embayment. During the final stages, the growth of the Old Teide stratovolcano was nested inside the collapse embayment with a slight offset to the east. Most of the lavas flowed toward the eastern part of Las Cañadas Caldera. These lavas have not been observed outside the inferred (buried) western rim of the collapse embayment, and only one flow spilled over the breached NE rim of the caldera above the Orotava Valley, halting at $900 \mathrm{~m}$ a.s.l. (see Fig. 4A). Only the Pico Viejo lavas overflowed the western caldera rim and spread over the northwestern and southwestern flanks of Las Cañadas Volcano.

The eruptive activity that formed the Teide Volcano was co-eval with eruptions from the NE and NW rifts, explaining the sequences of alternating phonolitic and basaltic pyroclastic layers observable in road cuts and in the galerias. An interesting feature of Teide Volcano is the phreatomagmatic eruption located on the NW flank of the main stratovolcano (Pérez Torrado et al., 2004). The explosive, surge-type episodes, probably related to snow-melt water interacting with the shallow magma during the eruption, formed thick slabs of indurated, whitish-color breccias interbedded within the final phonolitic lavas of the Old Teide Volcano and are overlain by lavas of Pico Viejo and the Lavas Negras of the terminal $1150 \pm 140$ cal yr BP eruption of Teide (Fig. 4A). This phreatomagmatic center, topped in the vent area by the Lavas Negras, probably forms the bulge interpreted by Ablay and Martí (2000) as the headwall of the Icod-La Guancha collapse.

\section{The Pico Viejo volcano}


Early lavas of Pico Viejo Volcano almost completely resurfaced the western side of the collapse embayment from about $30 \mathrm{ka}$ (Fig. 7 and Table 1), probably coinciding with the declining activity of Teide Volcano. The elevation of Pico Viejo (3100 m a.s.1.) is deceiving, because the entire edifice forms a relatively thin mantle on the western flank of the older Teide Volcano (see cross section in Fig. 7B). This elevation is, therefore, mainly due to the location of the vent at about $3000 \mathrm{~m}$ on the flank of the preexisting Teide edifice. Furthermore, the lava flows of Pico Viejo consistently overlie the Teide Volcano lavas, with the noted exception of the summit eruption (see Fig. 4C).

All these features suggest that the Pico Viejo is an adventive polygenetic volcano, probably originated by the decreasing gas pressure in a waning magma chamber required to feed magma to the summit of the Teide stratocone, thus favoring the opening of flank vents. Furthermore, the growing mass of the Teide stratocone increases the lithostatic load on the shallow magma chamber and the distance the magma has to ascend to the surface, imposing a limit above which summit eruptions will be physically unlikely (Davidson and De Silva, 2000). The apparent migration of most of the eruptive activity of the volcanic system to the west, as evidenced by more abundant Holocene volcanism in the NW Rift, implies diversion of magma transport to the new vents, in a process coinciding with the abrupt decline of the Teide Volcano.

The earlier eruptions of Pico Viejo, consisting of plagioclase basalts with distinct pahoehoe morphologies, entered into the western part of Las Cañadas Caldera and overflowed the western collapse embayment boundary, spread over the NW and SW flanks and reached the SW coast near Puerto de Santiago and from Icod to Santo Domingo, at the north (Figs. 3 and 7). These older lavas yielded a radiocarbon age of $27,030 \pm 430 \mathrm{yr}$ BP (Table 1), coinciding with the end of the main activity of Teide Volcano.

Subsequent volcanism erupted more differentiated lavas (tephrites to tephri-phonolites) in a series of flows dated at 20,775 \pm 321 yr BP (Table 1) extending toward the N, W and SW. The final stage of Pico Viejo activity comprised phonolitic eruptions dated at 17,525 \pm 365 cal yr BP (Table 1) that entered the western and eastern parts of Las Cañadas Caldera and spread toward the N, W and SW.

Activity at Pico Viejo Volcano persisted until recent times, with minor eruptions at the rim and inside the main crater. Alternatively, Pico Viejo Volcano may be inactive since about $17 \mathrm{ka}$ and the Holocene eruptions located at the summit of Pico Viejo Volcano may be related to the NW Rift and the parasitic lava domes of Teide Volcano. In one of these eruptions, probably connected to the emplacement of the Roques Blancos lava dome $(1714 \pm 151 \mathrm{cal}$ yr BP, Table 1), intense phreatomagmatic explosive phases removed part of the summit of the edifice. As in the case for Teide Volcano, this explosive event was probably driven by snow-melt water interacting with the shallow magma during the eruption. An explosion crater formed and brecciated material mantled the upper flanks of the volcano (see Fig. 7). 


\section{The peripheral lava domes and coulees}

Lava domes and coulees encircling Teide and Pico Viejo Volcanoes are parasitic eruptions of the main Teide stratovolcano (Fig. 8). As mentioned earlier, it seems evident that early in the Holocene the height of both main volcanoes impeded eruption of the viscous phonolitic lavas characteristic of the lava domes in the summit areas, and thus favored the emplacement of flank eruptions at the basal perimeter of the stratocones. The greater part of these parasitic lava-dome eruptions, particularly the coulees with less differentiated and less viscous lavas, are clearly associated with radial fractures at the lower part of Teide (Fig. 8).

As described above, most of the exposed lava domes and coulees have been dated, and their ages range from about $9210 \pm 190$ to $1714 \pm 151$ cal yr BP (Table 1), contributing considerably to the relatively high frequency of eruptive events in the central part of Tenerife. Silicic, generally andesitic, lava domes are very common, and the literature pertaining to these features is abundant. However, phonolitic lava domes and coulees of this volume and flow length are quite rare in oceanic islands. Depending on lava composition and topography, the lava domes in the central volcanic system of Tenerife define three main types of features: 1) symmetrical, hemispherical domes composed of viscous phonolitic glassy lavas are formed on flat surfaces (e.g., Mña. Rajada); 2) characteristic "rosette" structures, formed by many small flows like petals covering the surface of the dome (e.g., Abejera Alta, Abejera Baja, Abrunco, Pico Cabras); and 3) foliation, welldeveloped lava levees, and conspicuous pressure ridges, generated in very thick (up to 50-80 m) lava flows when the pressure of the outflowing lava compresses and forces the flow to move forward (e.g., Mña. Majúa, Mña. de la Cruz, Tabonal Negro).

In general, lava-dome eruptions tend to generate associated explosive episodes, forming extensive airfall deposits of pumice and collapse of the front of the coulees and giving rise to hot avalanches and blockand-ash flows or surges. However, no evidence of pyroclastic flows associated with such lava domes has been observed at Tenerife, although block and ash deposits related to this type of small hot avalanches have been found on the islands of La Palma and El Hierro (Carracedo et al., 2001). Air-fall pumice deposits are ubiquitous, and generally composed of thin (cm-scale) layers. A thicker (about $1 \mathrm{~m}$ ) and more extensive layer of pumice covers the $\mathrm{N}$ and NE flanks of the Teide stratocone and products of all the eruptions except the Roques Blancos and the most recent eruption of Teide. This air-fall pumice yields a radiocarbon age of $1986 \pm 165$ cal yr BP (Table 1), and most probably corresponds to the Mña. Blanca eruption, of similar age (Ablay et al., 1995).

\section{The prehistoric eruptive record}


Except the 1705 event of Mña. Arafo-Fasnia-Siete Fuentes, eruptions in the NE rift are pre-Holocene (Figs. 3 and 5). The most recent prehistoric eruption of the central volcanic complex is the latest eruption

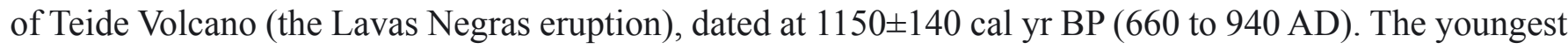
eruption in the NW Rift, with the exception of the historical events of 1706, 1798 and 1909, is Mña. Boca

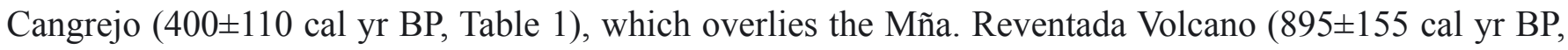
Table 1). The Boca Cangrejo Volcano is, therefore, the only eruptive event that took place and left a record preserved in the central part of Tenerife from about $900 \mathrm{yr}$ BP to 1496, when the island was colonized. Thus, many mentions of possible activity made by sailors during this period must then be attributed not to eruptions of Teide Volcano but to forest fires, fumarolic activity at the summit crater of Teide, or to meteorological phenomena. Boca Cangrejo Volcano, a relatively small cinder cone (80 m-high, $700 \mathrm{~m}-$ wide) located $1 \mathrm{~km}$ south of the historical (1909) vent of Chinyero, yielded a radiocarbon age consistent with the 1492 reference of Christopher Columbus. Therefore, we consider this event among the historical eruptions of Tenerife.

\section{Structural evolution of the rifts and the central volcanoes: the origin of nested central volcanoes in oceanic islands}

The main structural features of the latest, post-collapse, volcanic phase of Tenerife are shown in Figure 3. Two steep-slope, two-sided rift zones converge at the center of a collapse embayment, where a composite volcano developed nested inside the horseshoe-shaped depression. Eruptive centers cluster along the axis of the rifts, while the lavas flow down both flanks of the rifts. Lava flows from the central composite volcano expand radially; those converging inside the head wall of the collapse embayment (the Las Cañadas Caldera) form a thick sequence of horizontal lavas, whereas the northbound lavas flowed toward the coast inside the lower part of the depression (the Icod-La Guancha Valley).

As mentioned above, the construction of these stratovolcanoes nested in a collapse embayment is closely related to activity along the rifts (Carracedo, 1994; Carracedo et al., 2004), and it is therefore difficult to mark a clear boundary between the two volcanic systems, either spatially or between the processes that created them. Similarly nested volcanoes were also formed in the western Canaries; one of the best examples, the Bejenado volcano, in La Palma, shows its entire structure, completed in less than 50 k.y. after the Cumbre Nueva collapse (Carracedo et al., 1999a,b; 2001; Drury et al., 1999; Nelson et al., 2005).

In Tenerife, the construction of the nested composite volcanoes began immediately after the gravitational landslide that formed the Las Cañadas Caldera and the Icod-La Guancha Valley (Fig. 9-1), probably coinciding with a phase of intense eruptive and intrusive activity in both rift zones. The initial stages 
comprised the filling in of the depression by the first sequence of basanitic lavas (198 $\pm 5 \mathrm{ka})$, directly emplaced over the debris avalanche deposits.

In this model, the controversy about the nature of the collapse-vertical vs. lateral-is of minor relevance. Even if an initially vertical collapse occurred, the ensuing lateral slide would have formed the Las CañadasIcod Valley depression. Nonetheless, vertical collapse as the origin for the Las Cañadas Caldera, as well as the Güímar and La Orotava Valleys, as proposed by Araña (1971) and Martí et al. (1997), is far from evident. Geological information obtained in the Canaries, onshore (Navarro and Coello, 1989; Ancochea et al., 1990, 1999; Carracedo, 1994, 1999; Carracedo et al., 1999a, 1999b, 2001) and offshore (Watts and Masson, 1995; Urgelés et al., 1997, 1999; Masson et al., 2002), support a lateral collapse as the dominant mechanism generating not only the valleys of Güímar and La Orotava, and the Cañadas Caldera in Tenerife, but also many other similar features in the Canaries where explosive felsic volcanism was completely absent.

The only undisputed vertical collapse caldera in the Canaries is located in Gran Canaria (Caldera de Tejeda) and is related to much more intense explosive volcanism during the late shield stage of development of this island (Troll et al., 2002). A single event (P1) involved an estimated volume of $100 \mathrm{~km}^{3}$, possibly 180 $\mathrm{km}^{3}$ if the submarine extension of the unit is considered (Freundt and Schmincke, 1998). Conversely, the volume estimated by Martí et al. (1997) for the large-volume plinian and ignimbritic eruptions associated with the formation of the Las Cañadas Caldera is considerably lower, and it is divided into many events separated by long periods of quiescence, as indicated by interbedded paleosols (Navarro and Coello, 1989). The Island of Gran Canaria continued to have felsic, explosive volcanism (the Roque Nublo volcano) during the post-erosional stage, but apparently only lateral collapses have been documented for this stage (Pérez Torrado et al., 1997; Mehl and Schmincke, 1999).

The debris-avalanche deposits observed off-shore north of Tenerife and inland in galerías can be explained, as for the other islands, by lateral collapses (Carracedo, 1994, 1999; Watts and Masson, 1995; Carracedo et al., 2001, 2002; Masson et al., 2002). Conversely, the vertical-collapse model alone cannot explain these deposits, and requires a quite complex series of vertical to lateral failures. Furthermore, the geochronological and petrological data obtained for samples collected in galerías, particularly in Salto del Frontón, are apparently in conflict with a vertical-collapse genesis of this depression and the filling of the embayment with mafic lavas, similar to those of the rifts, just after the lateral collapse, directly over the debris-avalanche deposits. A lateral gravitational collapse of an unstable volcano possibly triggered by intense rift volcanism and dyke-induced stresses is a more likely alternative.

Large volumes of basaltic lavas were erupted at high eruptive rates in the initial stages after the lateral 
collapse, possibly due to depressurization following the landslide. These lavas filled the depression relatively rapidly, at a larger eruptive rate at the confluence of the rifts, causing an embryonic central volcano to form nested inside the landslide embayment (Fig. 9-2).

With continuing activity, the increasing height of the growing volcanic edifice progressively hindered the ascent of magma to the summit vents (Davidson and De Silva, 2000). Consequently, the frequency of central eruptions declined, and magma tended to accumulate below and within the volcano itself, generating a shallow magma chamber where, due to longer residence times, fractional crystallization processes generated large volumes of progressively more evolved magmas (Fig. 9-3). This process can be observed in the galerías located in the northern face of Teide, where the lavas mark a progressive change beginning at about $115 \mathrm{ka}$ from basaltic to intermediate and finally phonolitic compositions. This gradation in lava compositions in a nested volcano also characterizes the Bejenado volcano on La Palma (Drury et al., 1999; Carracedo et al., 1999a,b, 2001; Nelson et al., 2005).

The construction of Teide culminated with late phonolitic eruptions at around $30 \mathrm{ka}$, resulting in a 3500 m-high stratocone with a large crater open toward the east. Since then, Teide only had the $1150 \mathrm{yr}$ BP summit eruption that created the terminal cone and produced black phonolitic obsidian that gave the volcano its current height and configuration (Fig. 9-4).

The great height attained by the Teide at about $30 \mathrm{ka}$ favored the migration of eruptive conduits toward the northwest rift, thereby initiating the construction of a new composite, parasitic volcano, Pico Viejo, whose lavas, initially basaltic and later intermediate and phonolitic, that consistently overlie the Teide volcanics with the exception of the $1150 \mathrm{yr}$ BP Lavas Negras. The main phase of completion of Pico Viejo growth ended about $17 \mathrm{ka}$ with the eruption of phonolitic lavas which apparently drained the magma reservoir to form an $800 \mathrm{~m}$-wide crater, later partially filled by recent (Holocene) volcanic products. The height reached by both stratocones hindered magma transport to the summit craters, instead favored lateral eruptions in the form of lava domes and coulees at the basal perimeter of both stratovolcanoes (see Fig. 94), with the sole exception of the $1150 \mathrm{yr}$ BP summit eruption of Teide mentioned earlier, and a few small vents along the rim and within the interior of the Pico Viejo crater.

Throughout the entire process, the magma supplying the eruptions at the distal part of the rifts continued to be of basaltic composition, while simultaneous volcanism in the central volcanic system was consistently phonolitic, leading to a clear bimodal distribution of the composition of lavas along the axes of the rift zones (Fig. 9-4). This is consistent with the observations of Fúster et al. (1968), Ablay et al. (1998) and Rodríguez Badiola et al. (2006). 


\section{TIME -VOLUME RELATIONSHIPS AND VOLCANO STABILITY \\ Eruptive frequencies, volume estimates and eruptive rates}

The previous lack of radioisotopic ages for eruptions of the latest volcanic phase of Tenerife led to speculations regarding the frequency of eruptive events and the duration of inter-eruptive periods. Based on a few historical eruptions and unreliable eruption sightings of early sailors, a recurrence interval of 30 years was proposed (equivalent to about 30 eruptions per millennium), thus suggesting a high probability of short-term eruptions on the island and associated volcanic hazards (Araña et al., 2000). However, our radioisotopic ages of the most recent eruptive activity of the island (the last 30 k.y., particularly the Holocene volcanism) shows that this eruptive frequency is overestimated. We calculate approximately the frequency of Holocene eruptive events to be one order of magnitude lower than previous estimates, yielding a mean value of 3-7 eruptions per millennium (Fig. 10), although the number of eruptive events may be substantially higher than that of the eruptions that leave a recognizable geological record.

This apparently lower frequency and magma production rate are consistent with Tenerife being in its post-erosional stage of evolution, in which rift activity is considerably lower than that for the main-stage islands of La Palma and El Hierro (Ancochea et al., 1994; Carracedo et al., 1998, 2001; Guillou et al., 1996,1998, 2001). The morphology and structure of the rifts of Tenerife show an intermediate stage of evolution between similar features in the eastern (oldest) and western (youngest) islands. In comparison, the NE Lanzarote rift is formed by eruptive centers scattered over a very long period ( $>1$ My.) and a much broader spatial distribution. The resulting structure lacks the main alignment and the characteristic structure of the main-stage rifts, with the eruptive vents tightly grouped along the rift axis and the lava flows spreading down the steep flanks of the rift, well represented by the Cumbre Vieja Volcano, in the Island of La Palma. Nevertheless, the combined activity of the rifts and the central volcanic complex of Tenerife was sufficient to resurface the central part of the island bounded by the Teno massif over the last 30 k.y. (Fig. 11). Most of the present outcrops are associated with Holocene volcanism.

\section{Cumulative eruptive rates}

Eruptive rates over periods of thousands of years can be determined using a detailed chronology combined with volumetric estimates of the successive volcanic units. In this work the chronology is based on the radioisotopic ages, and the volumetric estimates based on the thickness and lateral extent calculated from Geographic Information System (GIS) digital geological maps (included in the Data Repository). The thickness of the volcanic sequences filling the collapse embayment has been determined from galerias and coastal cliffs. Post-collapse volcanism (younger than $200 \mathrm{ka}$ ) is fairly well preserved, allowing for accurate 
volume estimates. However, the evaluation of eruptive rates is difficult in the initial stages of filling of the collapse embayment because of the poorly constrained geochronology, and in the older eruptions of the NW rift, covered by recent eruptive products.

The erupted volumes were obtained by combining in ArcGIS the geological map, field measurements (margins and thickness of lava flows) and a DEM with a resolution of $20 \mathrm{~m} /$ pixel. The stratigraphy exposed along galerias and boreholes provided information about the tridimensional structure of the volcanic complex and the preexisting topography. The estimated error is $(<10 \%)$ is based on the comparison between volumetric estimates based on (1) the average thickness and lateral extent of the erupted units and (2) the cut-and-fill of pre-eruption and post-eruption DEMs. We used both methods systematically, except for the oldest eruptive units, whose initial extent could not be digitized. The results are presented in Fig. 12A and Table 3 that summarizes the eruptive rates deduced from the new ages and volume estimates.

The cumulative eruptive volumes and eruptive rates for the Teide volcanic complex underline a decreasing volcanic activity, from a basaltic effusive volcanism filling the flank collapse at $1.2 \mathrm{~km}^{3} / \mathrm{k} . \mathrm{y}$., to only one phonolitic eruption during the last $30 \mathrm{k} . \mathrm{y}$. The magmatic evolution, from basaltic or basanitic lavas to intermediate and phonolitic lavas, is illustrated by a declining eruptive rate and a migration of the eruptive centers to the periphery of the volcano, especially domes. The Pico Viejo volcano display less evolved lavas than the peripheral lava domes of the Teide and higher eruptive rates $\left(1 \mathrm{~km}^{3} / \mathrm{k} . \mathrm{y}.\right)$, close to those of the basaltic eruptions of the NW rift zone $\left(0.8 \mathrm{~km}^{3} / \mathrm{k} . \mathrm{y}\right.$.). The Upper Pleistocene eruptions of the NE rift zone represent minor volumes $\left(9 \mathrm{~km}^{3}\right)$ considering the initial volume of the entire rift zone $\left(>200 \mathrm{~km}^{3}\right.$ in 900 k.y.), which clearly appears to be declining. The Pleistocene activity of the NW rift zone was reduced ( 0.1 $\mathrm{km}^{3} / \mathrm{k}$.y.) during the basaltic filling of the flank collapse. The Holocene eruptions along this rift represent only $5 \%$ of the entire structure $\left(210 \mathrm{~km}^{3}\right.$ in $\left.1150 \mathrm{k.y}.\right)$, but the eruptive frequency is in good agreement with a high eruptive rate and a migration of the basaltic volcanism from the central volcano to the NW rift zone.

Volume and eruptive rates have been calculated for the few long-lived volcanoes that have high-resolution eruptive histories determined, most of them arc volcanoes: Mount Adams (Hildreth and Lanphere, 1994), Tatara-San Pedro (Singer et al., 1997), Mount Baker (Hildreth et al., 2003a), Katmai (Hildreth et al., 2003b), Ceboruco-San Pedro (Frey et al., 2004), Seguam (Jicha and Singer, 2006), Mauna Loa (Lipman, 1995) and Kilauea (Dvorak and Dzurisin, 1993). When the estimates obtained for the Teide-Rift Zones volcanic complex of the latest volcanic phase of Tenerife (Fig. 12A) are compared with those of these volcanoes it is evident that the volumes and eruptive rates of Tenerife are much lower than those of the Hawaiian shields. Conversely, the curves of cumulative volumes for the latest volcanic phase of Tenerife suggest similarities 
in the long-term evolution of the eruptive rates for the arc volcanoes, although the intraplate Teide volcano displays significantly higher values (Fig. 12 B). However, erosion has not been comparatively significant in the latest volcanic phase of Tenerife, whereas in the above-mentioned arc volcanoes the preserved subaerial volume is only a fraction of the total volume erupted, since a significant part of these products has been removed by glacial or marine erosion (Jicha and Singer, 2006).

\section{IMPLICATIONS FOR VOLCANIC HAZARD ASSESSMENT}

The previous proposed frequency of volcanic eruptions for the latest volcanic phase of Tenerife has been overestimated by at least an order of magnitude (Araña et al., 2000). Holocene eruptions occurred in Tenerife with a mean of 3-7 events per millennium. Our data do not support the notion about a period of enhanced volcanic activity during the Holocene. Nevertheless, future rift and lava dome eruptions would pose a considerable risk for the densely populated areas in the northern and western parts of Tenerife, which were almost entirely resurfaced by lavas during the Holocene (Fig. 11).

The directions of flows from any future eruption can be anticipated, as well as the areas protected by topography (Fig. 13). Furthermore, the composition of magma and eruptive mechanisms of future eruptions are strongly conditioned by the location of vents, with basaltic fissure eruptions most probably taking place at the distal part of the rifts and felsic, more explosive, events associated with vents located in the central region, where these rifts converge and a shallow differentiated magma chamber exists. Intermediatecomposition and mixed-magma eruptions are expected in the transitional areas.

The sustained increasing structural instability of the main stage of growth of Teide Volcano seems to have been suspended at about $30 \mathrm{ka}$, when the main stratocone ceased to rapidly grow higher. Holocene activity on the northern, more unstable slopes of Teide formed at least 7 voluminous phonolitic lava domes without activating flank failures; on the contrary, these phonolitic accumulations seem to progressively buttress and increase the stability of the Teide stratocone.

The eruptive styles of Teide and Pico Viejo volcanoes have been dominantly effusive in the past; as observed in the galerias, pyroclastic material in the sequences filling the collapse embayment is almost entirely absent. Therefore, the eruptive styles during this cycle were totally different from that of the preceding volcanic stages of Las Cañadas Volcano, which involved more frequent explosive eruptions, including plinian events. The peripheral lava domes of Teide have produced somewhat more explosive eruptions than the characteristic fissure basalt (strombolian) eruptions of the intermediate and distal parts of the rifts, some of them such as Roques Blancos or Montaña Blanca in recent geological times.

Martí et al. (1997) proposed three main basaltic-to-phonolitic cycles prior to the final stage of development 
of the Las Cañadas Volcano; each cycle initiated with mafic or intermediate eruptions that then evolved toward phonolitic products. It is therefore possible that several pre-Teide cycles of rift activity occurred with similar characteristics (recurrent flank failures, filling of collapse depressions, and eventually building differentiated, nested composite volcanoes), and affected similar areas (Siebert, 1984). According to Martí et al. (1997), these cycles preceded the latest volcanic phase in which Teide Volcano formed. However, because these cycles take place in a post-erosional setting, driven by rift activity with much less energy than in rifts found at main-stage, ocean-island volcanoes (e.g., La Palma, El Hierro, Mauna Loa, Kilauea, etc.), their intensity would likely be declining, although this does not necessarily imply that this will be the last cycle to take place in the Island of Tenerife.

\section{CONCLUSIONS}

Detailed field mapping, volcanological analysis and radioisotopic dating $\left({ }^{14} \mathrm{C}\right.$ and $\left.\mathrm{K} / \mathrm{Ar}\right)$ provide the most detailed reconstruction to date of the eruptive and structural history of the latest volcanic phase of Tenerife, comprising the NW and NE rift zones and the Teide central volcanic complex. Over 50 new ages from stratigraphically controlled lavas and from the early stages of this volcanic phase provide a completely new geochronological framework. The results from this work contradict earlier studies that greatly overestimate the eruptive frequency and, consequently, the potential eruptive hazards on the island. Holocene eruptions on Tenerife have a mean frequency of 3-7 eruptions per millennium. The many purported sightings of volcanic activity in Tenerife prior to the colonization of the island in 1496 cannot be related with actual eruptions, but more likely to forest fires or meteorological phenomena. The exception is the observations by Christopher Columbus in 1492, corresponding to the Boca Cangrejo eruption (located in the NW Rift), which has a radiocarbon age consistent with this report.

The main volcanic units defined comprise the NW and NE rift zones and a central complex including the Teide and Pico Viejo volcanoes, the former the major stratocone, and the latter a parasitic composite volcano. Both stratocones are ringed by a cluster of basal lava domes and coulees of Holocene age. These main units, however, lack well-defined geological or temporal boundaries, forming an interactive system with rift activity as the main driving process. Volcanic and intrusive activity along both rift zones may have played an important role in activating the gravitational collapse of the northern flank of Las Cañadas Volcano at about $200 \mathrm{ka}$, filling the resulting embayment, and developing an increasingly higher central volcano with progressively differentiated magmas. The coeval growth of the central volcano with sustained activity at the rifts led to a clear bimodal distribution of eruption compositions, with the basaltic compositions in the distal part of the rifts and phonolitic compositions in the proximal and central (transitional) areas. Intermediate 
lavas and magma mixing processes predominate in the transitional zones.

No definitive field evidence of vertical caldera collapses has been found. Moreover, geochronological and petrological data, particularly from studies of lavas from the earlier sequences filling the collapse embayment, clearly support a northbound gravitational collapse. If any preceding vertical-collapse caldera existed, the landslide largely removed evidence for it.

The explosivity of the entire volcanic system is considerably lower than that described for the earlier, pre-collapse Las Cañadas Volcano. Rift activity and the early post-collapse sequences filling the collapse embayment are predominantly effusive. Eruptions ending in lava domes and coulees constitute the most explosive events, as evidenced only by scarce airfall deposits; no signs of pyroclastic flows or lava-dome collapses are seen in the geological record. Phreatomagmatic events in the Teide and Pico Viejo stratocones only generated localized explosions, as indicated by limited pyroclastic surge deposits and explosion breccias.

The cumulative eruptive volumes and eruptive rates of the Teide central volcanic complex underline a decreasing volcanic activity, from a basaltic effusive volcanism filling the flank collapse at $1.2 \mathrm{~km} / \mathrm{k} . \mathrm{y}$. to a single phonolitic eruption during the last 30 k.y. The Pico Viejo display less evolved lavas than the peripheral domes of the Teide and higher eruptive rates, similar to those of the NW rift zone during the Holocene, whereas the post-collapse Pleistocene activity of this rift zone was reduced because magma supply was mainly focused inside the collapse embayment. The Upper Pleistocene eruptions of the NE rift zone represent minor volumes considering the initial volume of the entire rift zone $\left(>200 \mathrm{~km}^{3}\right.$ in 900 k.y.), which definitely appears to be declining. Volumes and eruptive rates for the latest volcanic phase of Tenerife are much lower than those of the Hawaiian shields, and comparable to those determined for arc volcanoes.

Recurrent volcanic cycles, initiated with a gravitational collapse and ensuing mafic or intermediate eruptions that evolved toward phonolitic products, may have occurred in Tenerife. Declining activity in the Holocene suggests that Tenerife is at present in the final stages of the cycle that started about 200 ka. However, it is impossible to predict if this will be the last phase. Magmatic and eruptive rates can be expected to decline in the future for Tenerife, a posterosional island well advanced in this stage in its volcanic evolution.

Collectively, current volcanic hazards in Tenerife are inferred to be modest, because eruptive frequency is low, explosivity is moderate and the structural instability of the Teide stratocone seems to have declined over the last $30 \mathrm{k} . \mathrm{y}$., with the lava domes apparently contributing to lessen the edifice aspect ratio and to buttress the steeper northern flank of the volcano. However, the occurrence of lava-dome flank eruptions 
during the Holocene, combined with the Teide, Pico Viejo and NW Rift eruptions in the same period, still poses a significant lava-flow risk to the now densely populated areas in northern and western Tenerife, that have been almost entirely resurfaced by lava flows during the Holocene.

Based on the eruptive behavior of this latest volcanic phase of Tenerife, particularly in the Holocene, a tentative prediction can be made of what is likely to happen next: when, where and what. The low number and frequency of eruptions and the irregularity of the periods between eruptions (from a few years to several centuries) hinder any prediction of the probable time of occurrence of the next eruption. More precisions can be made on its location, most probably at the NW rift zone (60-80\%) or at the basal perimeter of the main stratovolcano $(20-40 \%)$. The more fundamented prediction is related to the composition and eruptive mechanisms of this eruption, based on its location in relation to the volcanic system formed by the NW rift and the Teide central complex: Fissure basaltic or intermediate composition eruptions can be expected along the NW rift zone, whereas phonolitic lava dome eruptions are more probable in the area of influence of the Teide central complex, inside the Las Cañadas caldera or at the head of the Icod-La Guancha valley.

\section{Acknowledgments}

Our most sincere thanks are due to Robert I. Tilling and Charlie Bacon for their careful reviews and many thoughtful comments that greatly helped us to improve the paper. We also thank Bruce Nelson, Valentin Troll, Andreas Klügel and Sebastian Wiesmaier for their comments and ideas that helped to significantly improve an earlier version of the manuscript. This work has been possible thanks to the financial support of the Caja General de Ahorros de Canarias and, recently, to the Spanish Plan Nacional de I+D+I research project CGL2005-00239/BTE. Financial support was also provided for the geochronological work by the CEA and CNRS. The personnel of the Teide National Park provided logistical support, crucial for the mapping and sampling. Alejandro García Martínez, Eloy Rodríguez Valdés, and Juan Manuel Cabrera spent many months preparing the samples and digitizing the GIS geological maps, and M. Castillejo and J.M. Hontoria preparing thin sections for the petrological analysis. Precise topographic maps and aerial photographs were provided by GRAFCAN.

\section{References}

Ablay, G.J., Ernst, G.G.J. , Martí, J., Sparks, R.S. J., 1995. The 2 ka subplinian eruption of Mña. Blanca, Tenerife. Bulletin of Volcanology 57: 337-355.

Ablay, G.J., Carroll, M.R., Palmer, M.R., Martí, J., Sparks, R.S.J., 1998. Basanite-phonolite lineages of the Teide-Pico Viejo Volcanic Complex, Tenerife, Canary Islands. Journal of Petrology 39 (5), 905-936. Ablay, G.J., Martí, J., 2000. Stratigraphy, structure, and volcanic evolution of the Pico Teide-Pico Viejo formation, Tenerife, Canary Islands. Journal of Volcanology and Geothermal Research 103: 175-208. 
Ancochea, E., Fúster, J.M., Ibarrola, E., Cendrero, A., Coello, J., Hernán, F., Cantagrel, J.M., Jamond, C., 1990. Volcanic evolution of the Island of Tenerife (Canary Islands) in the light of new K-Ar data. Journal of Volcanology and Geothermal Research 44: 231-249.

Ancochea, E., Hernán, F., Cendrero, A., Cantagrel, J.M., Fúster, J.M., Ibarrola, E. Coello, J., 1994. Constructive and destructive episodes in the building of a young oceanic island, La Palma, Canary Islands, and genesis of the Caldera de Taburiente. Journal of Volcanology and Geothermal Research 60; 3-4: 243-262.

Ancochea, E., Huertas, M. J., Cantagrel, J. M., Coello, J., Fúster, J. M., Arnaud, N., Ibarrola, E., 1999. Evolution of the Cañadas edifice and its implications for the origin of the Cañadas Caldera (Tenerife, Canary Islands). Journal of Volcanology and Geothermal Research 44: 177-199.

Araña V., 1971. Litología y estructura del edificio Cañadas, Tenerife (Islas Canarias). Estudios Geológicos 27: 95-135.

Araña, V., Aparicio, A., García Cacho, L., García García, R., 1989. Mezcla de magmas en la región central de Tenerife. In: Los Volcanes y la caldera del Parque Nacional del Teide (Tenerife, Islas Canarias). V. Araña, J. Coello (Eds.), ICONA, Madrid, 443 pp.

Araña, V., Felpeto, A., Astiz, M., García, A., Ortiz, R., Abella, R., 2000. Zonation of the main volcanic hazards (lava flows and ash falls) in Tenerife, CI. A proposal for a surveillance network. Journal of Volcanology and Geothermal Research 103: 377-391.

Cantagrel, J.M., Arnaud, N.O., Ancochea, E., Fúster, J.M., Huertas, M.J., 1999. Repeated debris avalanches on Tenerife and genesis of Las Cañadas caldera wall (Canary Islands). Geology 27: 739-742.

Carracedo, J.C., 1979. Paleomagnetismo e historia geológica de Tenerife. Aula Cultura Cabildo Insular de Tenerife, Santa Cruz de Tenerife, $81 \mathrm{pp}$.

Carracedo, J.C., 1994. The Canary Islands: an example of structural control on the growth of large oceanic island volcanoes. Journal of Volcanology and Geothermal Research 60: 225-242.

Carracedo, J.C., 1999. Growth, structure, instability and collapse of Canarian volcanoes and comparisons with Hawaiian volcanoes. Journal of Volcanology and Geothermal Research Special Issue, 94, 1-4: $1-19$.

Carracedo, J.C., Day, S., Guillou, H., Rodríguez Badiola, E., Canas, J.A., Pérez Torrado, F.J., 1998. Hotspot volcanism close to a passive continental margin: the Canary Islands. Geological Magazine 135: 591604.

Carracedo, J.C., Day, S., Guillou, H., Pérez Torrado, F.J., 1999a. Giant Quaternary landslides in the evolution of La Palma and El Hierro, Canary Islands. Journal of Volcanology and Geothermal Research Special Issue, 94, 1-4: 169-190.

Carracedo, J.C., Day, S., Guillou, H.. Gravestock, P., 1999b. The later stages of the volcanic and structural evolution of La Palma, Canary Islands: The Cumbre Nueva giant collapse and the Cumbre Vieja volcano. Geological Society of America Bulletin, 111-5: 755-768.

Carracedo, J.C., Rodríguez Badiola, E., Guillou, H., De La Nuez, J., Pérez Torrado, F.J., 2001. Geology and volcanology of La Palma and El Hierro (Canary Islands). Estudios Geológicos 57: 175-273.

Carracedo, J.C., Pérez Torrado, F.J., Ancochea, E., Meco, J., Hernán, F., Cubas, C.R., Casillas, R., Rodríguez Badiola, E., Ahijado, A., 2002. Cenozoic Volcanism II: The Canary Islands. In: The Geology of Spain. (Gibbons, W., Moreno, T. edis). The Geological Society, London, 632 pp.

Carracedo, J.C., Guillou, H., Paterne, M., Scaillet, S., Rodríguez Badiola, E., Pérez Torrado, F.J., Hansen, 
A., Paris, R., 2004. Nested central volcanism related to rift development and giant landsliding in oceanic islands. IAVCEI General Assembly, Pucón, Chile.

Charbit, S., Guillou, H., Turpin, L., 1998. Cross calibration of K-Ar standard minerals using an unspiked Ar measurements technique. Chemical Geology 150: 147-159.

Clague, D.A., 1987. Hawaiian xenolith populations, magma supply rates, and development of magma chambers. Bulletin of Volcanology 49, 4: 577-587.

Coello, J., 1973. Las series volcánicas en subsuelos de Tenerife. Estudios Geológicos 29: 491-512.

Davidson, J., De Silva, S., 2000. Composite volcanoes. In: Encyclopedia of Volcanoes. H. Sidgurdsson (ed.). Academic Press: 663-681.

Drury, R.M., Nelson, B.K., Carracedo, J.C., 1999. Tracing mantle heterogeneities and magmatic storage: Geochemical stratigraphy of the Bejenado Volcano, La Palma, Canary Islands (http://depts.washington. edu/isochem/research/lapalma.htm).

Dvorak, J.J., Dzurisin, D., 1993. Variations in magma-supply rate at Kilauea Volcano, Hawaii.Journal of Geophysical Research 98: 22,255-22,268.

Freundt, A., Schmincke, H.U., 1998. Emplacement of ash layers related to high-grade ignimbrite P1 in the sea around Gran Canaria. In: Weaver, P.P.E., Schmincke, H.U., Firth, J.V. \& Duffield, W. (Eds): Proc. ODP, Sci. Results, 157: College Station, TX (Ocean Drilling Program), pp. 201-218.

Frey, H.M., Lange, R.A., Hall, C.M., Delgado-Granados, H., 2004. Magma eruption rates constrained by 40Ar/39Ar chronology and GIS for the Ceboruco-San Pedro volcanic field, western Mexico. Geological Society of America Bulletin 116: 259-276.

Fúster, J.M., Araña, V., Brandle, J.L., Navarro, M., Alonso, U., Aparicio, A., 1968. Geología y volcanología de las Islas Canarias: Tenerife. Ins. "Lucas Mallada”, CSIC., Madrid, 218 pp.

Guillou, H., Carracedo, J.C., Pérez Torrado, F. and Rodríguez Badiola, E., 1996. K-Ar ages and magnetic stratigraphy of a hotspot-induced, fast grown oceanic island: El Hierro, Canary Islands. Journal of Volcanology and Geothermal Research 73: 141-155.

Guillou, H., Carracedo, J.C., Day, S.J., 1998. Dating of the Upper Pleistocene-Holocene volcanic activity of La Palma using the unspiked K-Ar technique. Journal of Volcanology and Geothermal Research 86: 137-149.

Guillou, H., Carracedo, J.C., Duncan, R., 2001. K-Ar, 40Ar/39Ar Ages and Magnetostratigraphy of Brunhes and Matuyama lava sequences from La Palma Island. Journal of Volcanology and Geothermal Research 106, 3-4: 175-194.

Guillou, H., Carracedo, J. C., Paris R., Pérez Torrado, F.J., 2004a. K/Ar ages and magnetic stratigraphy of the Miocene-Pliocene shield volcanoes of Tenerife, Canary Islands: Implications for the early evolution of Tenerife and the Canarian Hotspot age progression. Earth and Planetary Science Letters 222,:599-614.

Guillou, H., Pérez Torrado, F. J., Hansen Machin, A. R., Carracedo, J. C., Gimeno, D.. 2004b. The PlioQuaternary volcanic evolution of Gran Canaria based on new K-Ar ages and magnetostratigraphy. Journal of Volcanology and Geothermal Research 135: 221-246.

Guillou H., Singer B. Laj C., Kissel C., Scaillet S., Jicha B.R., 2004c. On the age of the Laschamp geomagnetic event. Earth and Planetary Science Letters 227: 331-343.

Hildreth, W., Lanphere, M.A., 1994. Potassium-argon geochronology of a basalt-andesite-dacite arc system: The Mount Adams volcanic field, Cascade Range of Southern Washington. Geological Society of 
America Bulletin 106: 1413-1429.

Hildreth, W., Fierstein, J., Lanphere, M.A., 2003a. Eruptive history and geochronology of the Mount Baker volcanic field, Washington. Geological Society of America Bulletin 115: 729-764.

Hildreth, W., Lanphere, M.A., Fierstein, J., 2003b. Geochronology and eruptive history of the Katmai volcanic cluster, Alaska Peninsula. Earth and Planetary Science Letters 214: 93-114.

Huertas, M. J., Arnaud, N. O., Ancochea, E., Cantagrel, J. M., Fúster J. M., 2002. 40Ar/39Ar Stratigraphy of main pyroclastic units from the Cañadas Volcanic Edifice (Tenerife, Canary Islands) and their bearing on structural evolution. Journal of Volcanology and Geothermal Research 115: 351-365.

Jicha, B.R., Singer, B.S., 2006. Volcanic history and magmatic evolution od Seguam Island, Aleutian Island arc, Alaska. Geological Society of America Bulletin 118: 805-822.

Klügel, A.; Hansteen, T.H., Schmincke, H.U. (1997).Rates of magma ascent and depths of magma reservoirs beneath La Palma (Canary Islands), Terra Nova 9, 3: 117-121.

Klügel, A., Hoernle, K.A., Schmincke, H.U., White, J.D.L., 1999. The chemically zoned 1949 eruption on La Palma (Canary Islands): Petrologic evolution and magma supply dynamics of a rift-zone eruption. Journal of Geophysical Research 94, 1-4: 267-282.

Lipman, P.W., 1995. Declining growth of Mauna Loa during the last 100,000 years: Rates of lava accumulation vs. gravitational subsidence. AGU Geophys. Monograph 92, J.M. Rodees and J.P. Lockwood, eds.: 45-80.

Lockwood, J.P., 1995. Mauna Loa eruptive history. The preliminary radiocarbon record. In: Mauna Loa revealed. Structure, composition, history and hazards. AGU Geophys. Monograph 92, J.M. Rodees and J.P. Lockwood, eds.: 81-94.

Martí, J., Mitjavila, J., Araña, V., 1994. Stratigraphy, structure and geochronology of the Las Cañadas Caldera (Tenerife, Canary Islands). Geological Magazine 131: 715-727.

Martí, J., Hurlimann, M., Ablay, G.J., Gudmundsson, A., 1997. Vertical and lateral collapses on Tenerife (Canary Islands) and other volcanic ocean islands. Geology 25: 879-882.

Martí, J., Gudmundsson, A., 2000. The Las Cañadas caldera (Tenerife, Canary Islands): an overlapping collapse caldera generated by magma-chamber migration. Journal of Volcanology and Geothermal Research 103: 167-173.

Mitjavila, J., 1990. Aplicación de técnicas de geoquímica isotópica y de geocronología al estudio vulcanológico del edificio de Diego Hernández y su relación con la Caldera de Las Cañadas (Tenerife). PhD Thesis, Universidad de Barcelona, $258 \mathrm{pp}$.

Mitjavila, J., Vila, L., 1993. Temporal evolution of Diego Hernández formation (Las Cañadas, Tenerife) and confirmation of the age of the caldera using the 40Ar/39Ar method. Revista de la Sociedad Geológica de España 6: 61-65.

Masson, D.G., Watts, A.B., Gee, M.J.R., Urgelés, R., Mitchell, N.C., Le Bas, T.P., Canals, M., 2002. Slope failures on the flanks of the western Canary Islands. Earth Science Reviews 57: 1-35.

Mehl, K. W., Schmincke, H.U., 1999. Structure and emplacement of the Pliocene Roque Nublo debris avalanche deposit, Gran Canaria, Spain. Journal of Volcanology and Geothermal Research 94: 105 134.

Moore, J.G., 1964. Giant submarine landslides on the Hawaiian Ridge. U.S. Geological Survey Professional Paper 501-D: D95-D98.

Navarro, J.M., 1980. Plano geológico del Complejo Teide-Pico Viejo. En: Islas Canarias, Excursión 121 
A + C, Vol. Esp., 26 Congreso Geológico Internacional, París, 1980. Boletín Geológico y Minero 912.

Navarro, J.M., Coello, J., 1989. Depressions originated by land-slide processes in Tenerife, ESF Meeting on Canarian Volcanoes, Lanzarote: 150-152.

Nelson, B.K., Carracedo, J.C., Badiola, E.R., Hamilton, A., Guetschow, H., 2005. Spatial and temporal isotopic gradients in the Western Canary Islands. AGU Fall Meeting Abstracts, 1471.

Paris, R., Guillou, H., Carracedo, J.C., Pérez-Torrado, F.J., 2005. Volcanic and morphological evolution of La Gomera (Canary Islands), based on new K-Ar ages and magnetic stratigraphy: implications for oceanic island evolution. Journal of the Geological Society, London 162: 501-512.

Pérez Torrado, F.J., 2000. Volcanoestratigrafía del Grupo Roque Nublo (Gran Canaria). Ed. Servicio de Publicaciones del Cabildo de Gran Canaria y de la Universidad de Las Palmas de Gran Canaria: 459 pp.

Pérez Torrado, F.J., Day, S.J., Carracedo, J.C., 1997. Growth and destruction by lateral collapse of the Roque Nublo oceanic island stratovolcano, Gran Canaria, Canary Islands. International Workshop on Volcanism and Volcanic Hazards in Immature Intraplate Oceanic Islands, La Palma, Canary Islands. Abstracts book: 67-69.

Pérez Torrado, F.J., Carracedo, J.C., Paris, R., Hansen, A., 2004. Descubrimiento de depósitos freatomagmáticos en las laderas septentrionales del estratovolcán Teide (Tenerife, Islas Canarias): relaciones estratigráficas e implicaciones volcánicas. Geotemas 6 (1): 163-166.

Reimer, P.J., Baillie, M.G.L., Bard, E., Bayliss, A., Beck, J., Warren, B., Chanda J.H., Blackwell, P.G., Buck, C.E., Burr, G.S., Cutler, K.B., Damon, P.E., Edwards, R.L., Fairbanks, R.G., Friedrich, M., Guilderson, T.P., Hogg, A.G., Hughen, K.A., Kromer, B., McCormac, G., Manning, S., Ramsey, C.B., Reimer, R.W., Remmele, S., Southon, J.R., Stuiver, M., Talamo, S., Taylor, F.W., van der Plicht, J., Weyhenmeyer, C.E., 2004. IntCa104 Terrestrial Radiocarbon Age Calibration, 0-26 Cal Kyr BP. Radiocarbon 46, 3: 1029-1058.

Rodríguez Badiola, E., Pérez Torrado, F.J., Carracedo, J.C. y Guillou, H., 2006. Petrografía y geoquímica del edificio volcánico Teide-Pico Viejo y las dorsales noreste y noroeste de Tenerife. en: J.C. Carracedo (ed.) Los Volcanes del Parque Nacional del Teide. Serie Técnica. Pub. Organismo Autónomo Parques Nacionales, MOMA, Madrid: 129-188.

Rubin, M., Gargulinski, L.K., McGeehin, J.P., 1987. Hawaiian radiocarbon dates. In: R.W. Decker, T.L. Wright and P.H. Stauffer, eds., Volcanism in Hawaii, U.S. Geological Survey Proffesional Paper 1350, 1, 10: 213-242.

Scaillet, S., Guillou, H., 2004. A critical evaluation of young (near zero) K-Ar Ages. Earth and Planetary Science Letters 220: 265-275.

Schmincke, H.U., 1979. Age and crustal structure of the Canary Islands. Journal of Geophysics 46: 217 224.

Schmincke, H.U., 1982. Volcanic and chemical evolution of the Canary Islands. In Von Rad, U. et al. (eds). Geology of the Northwest African Continental Margin. Springer Verlag: 273-276.

Siebert, L., 1984. Large volcanic debris avalanches: Characteristics of source areas, deposits, and associated eruptions. Journal of Volcanology and Geothermal Research 22: 163-197.

Singer, B.S., Thompson, R.A., Dungan, M.A., Feelley, T.C., Nelson, S.T., Pickens, J.C., Brown, L.L., Wulff, A.W., Davidson, J.P., Metzger, J., 1997. Volcanism and erosion during the past 930 ky at the 
Tatara-San Pedro complex, Chilean Andes. Geological Society of America Bulletin 109: 127-142.

Steiger, R.H., Jager, E., 1977. Convention on the use of decay constants in geo- and cosmochronology. Earth and Planetary Science Letters 36: 359-362.

Stillman, C.J., 1999. Giant Miocene landslides and the evolution of Fuerteventura, Canary Islands. Journal of Volcanology and Geothermal Research Special Issue 94, 1-4: 89-104.

Thirlwall, M.F., Singer, B.S., Marriner, G.F., 2000. 39Ar-40Ar ages and geochemistry of the basaltic shield stage of Tenerife, Canary Islands, Spain. Journal of Volcanology and Geothermal Research 103: 247297.

Tilling, R.1., Heliker, C., Wright, T.L., 1989, Eruptions of Hawaiian volcanoes: Past, present, and future: Reston, Virginia, U.S. Geological Survey, 54 p.

Troll, V.R., Walter, T.R., Schmincke, H.U., 2002. Cyclic caldera collapse: Piston or piecemeal subsidence? Field and experimental evidence. Geology 30, 2: 135-138.

Urgelés, R., Canals, M., Baraza, J., Alonso, B., Masson, D.G., 1997. The last major megalandslides in the Canary Islands: The El Golfo debris avalanche and the Canary debris flow, west Hierro Island. Journal of Geophysical Research 102: 20305-20323.

Urgelés, R., Masson, D.G., Canals, M., Watts, A.B., Le Bas, T., 1999. Recurrent large-scale landsliding on the west flank of La Palma, Canary Islands. Journal of Geophysical Research 104: 25331-25348.

Walker, G.P.L., 1990. Geology and volcanology of the Hawaiian Islands. Pacific Science 44: 315--347.

Walter, T.R., Troll, V.R., Cailleau, B., Belousov. A., Schmincke, H.U., Amelung, F., Bogaard, P., 2005. Rift zone reorganization through flank instability in ocean island volcanoes: An example from Tenerife, Canary Islands. Bulletin of Volcanology 67 (4):281-291.

Watts, A.B., Masson, D. G., 1995. A giant landslide on the north flank of Tenerife, Canary Islands. Journal of Geophysical Research 100 (B2): 24487-24498.

\section{FIGURE CAPTIONS}

Fig. 1. Simplified geological map of the Island of Tenerife showing the main volcanic features. The map and the cross section below show the three Mio-Pliocene shields that built the island in the periods indicated. The post-erosional Las Cañadas volcano and the rift zones are shown unconformably overlying the older volcanoes. This stage represents the latest eruptive cycle of the island, comprising the younger part of the NW and NE rift zones and the post-caldera Teide-Pico Viejo composite volcanoes (modified from Fúster et al., 1968, Carracedo, 1979, Ancochea et al., 1990 and Guillou et al., 2004a).

Fig. 2. Locations of samples collected for radiocarbon and $\mathrm{K} / \mathrm{Ar}$ dating. Only the most reliable part of the abundant wood charcoal fragments found have been dated, those clearly overlain by a lava flow (see appendix), thus giving a maximum age for the eruption.

Fig. 3. Geological map of the main units of the latest volcanic phase of Tenerife.

Fig. 4. A. Geological map of the Teide volcano and the inferred distribution of lavas from the earliest 
stages of filling of the collapse embayment. Ages in calibrated years BP (see Tables 1 and 2). B. Cross section of the open, horseshoe-shaped caldera (Caldera de Las Cañadas) that extends toward the north coast, forming the La Guancha-Icod valley, as the result of a gravitational lateral collapse of the preceding Las Cañadas volcano. The galería Salto del Frontón is shown penetrating the entire post-collapse sequence. C. Section along the Galería Salto del Frontón showing the composition and age of the volcanic formations filling the collapse embayment. The deepest part of the section, from about $3400 \mathrm{~m}$., was not suitable for dating because of the high degree of alteration.

Fig. 5. A. Geological map of the NE rift zone. B. Cross section showing the stratigraphic disposition of the eruptions along the NE rift. Ages in calibrated years BP (see Tables 1 and 2).

Fig. 6. A. Geological map of the NW rift zone. The eruptions are numbered. B. Cross section showing the stratigraphic arrangement of the eruptions in the NW rift. Ages in calibrated years BP (see Tables 1 and 2).

Fig. 7. A. Geological map of Pico Viejo Volcano and the inferred distribution of its erupted. B. Cross section showing the stratigraphic arrangement of the succeeding volcanic units. Ages in calibrated years BP (see Tables 1 and 2).

Fig. 8. A. Geological map of the parasitic lava domes and coulees of the Teide and Pico Viejo stratocones. B. Cross section showing the stratigraphic arrangement of the volcanic units. Ages in calibrated years BP (see Table 1).

Fig. 9. Cartoon illustrating the role of rifts in the growth of nested differentiated composite volcanoes. See text for explanation.

Fig. 10. Age and frequency of the Holocene eruptions of the NW and NE rift zones and the central volcanic complex of Tenerife. Dated eruptions (in cal yr BP) in bold; phonolitic eruptions in italic.

Fig. 11. Cumulative resurfacing of the central and western areas of Tenerife by lava flows from Holocene eruptions.

Fig. 12. A. Cumulative eruptive volumes versus time for the Teide volcanic complex and rift-zones of Tenerife. The thin curves represent the cumulative eruptive volumes of the main volcanic units, and the thick curves, the cumulative eruptive volumes of the basaltic volcanism and evolved phonolitic volcanism. B. Cumulative eruptive volumes versus time for the Teide Volcano and other well-dated volcanoes (modified after Jicha \& Singer, 2006; data after Hildreth \& Lanphere, 1994; Singer et al., 1997; Hildreth et al., 2003a and 2003b; Frey et al., 2004).

Fig. 13. Simplified map of the lava-flow hazards related to the most recent volcanic phase of Tenerife. Nine hazard zones are shown, with Zone 1 the most severe: 1. NW Rift, with highest probability of occurrence 
of basaltic and intermediate strombolian eruptions; 2. Southern flank of the NW rift, area of probable distribution of flows from Zone 1; 3. Area of probable distribution of flows from Zone 1 for the northern flank; 4. Moderate probability of weakly explosive phonolitic eruptions of the stratocones and parasitic lava-domes and coulees collected inside Las Cañadas Caldera; 5. Moderate probability of low-explosive phonolitic eruptions of the stratocones and parasitic lava-domes and coulees flowing downslope to the northern coast; 6. NE Rift, with low probability of occurrence of basaltic and intermediate strombolian vents, with lavas flowing toward the south-eastern coast (7) and on the northern flank (8) inside the La Orotava Valley; 9. Very low probability of occurrence of basaltic and intermediate strombolian vents at the distal part of the NW rift zone, at the top and flanks of the Teno massif. The entire system apparently shows a northwesterly general migration of volcanism. TP: Areas protected by topography. BR: breached parts of the rim of Las Cañadas Caldera, possibly allowing lavas to overflow the caldera. In the breached part of the western semi-caldera, the rim is only 20 -m high at the head of a deep gulch, thereby posing a threat to the town of Playa de San Juan on the southwest coast. 
Table 1. Radiocarbon ages from samples of the Teide, Pico Viejo and the NW and NE Rift zones of Tenerife

\begin{tabular}{|c|c|c|c|c|c|}
\hline Sample & Volcanic Unit (UTM) & Material & Method & $\begin{array}{l}{ }^{14} \mathrm{C} \text { age yr } \\
\mathrm{BP} \pm 2 \sigma\end{array}$ & Calibrated age yr $\mathrm{BP} \pm 2 \sigma$ \\
\hline \multicolumn{6}{|c|}{ NW RIFT ZONE } \\
\hline TFC- $442^{2}$ & $\begin{array}{l}\text { Mña. Boca Cangrejo } \\
\text { 326.38/3.129.2 }\end{array}$ & $\begin{array}{l}\text { Charcoal under basaltic } \\
\text { scoria }\end{array}$ & Radiometric & $350 \pm 60$ & $\begin{array}{l}510 \text { to } 290(400 \pm 110) \\
1440 \text { to } 1660 \mathrm{AD}\end{array}$ \\
\hline TFC- $369^{2}$ & $\begin{array}{l}\text { Mña. Reventada } \\
327583-3132080\end{array}$ & $\begin{array}{l}\text { Charcoal under benmoreite } \\
\text { flow }\end{array}$ & $\begin{array}{l}\text { Radiometric } \\
\text { (ext.coun.) }\end{array}$ & $990 \pm 70$ & $\begin{array}{l}1050 \text { to } 740(895 \pm 155) \\
900 \text { to } 1210 \mathrm{AD}\end{array}$ \\
\hline TFC-219 1 & $\begin{array}{l}\text { Los Hornitos } \\
331441-3125134\end{array}$ & Charcoal under hawaiite flow & AMS & $1930 \pm 80$ & $\begin{array}{l}1988 \text { to } 1741(1864 \pm 123) \\
39 B C \text { to } 209 A D\end{array}$ \\
\hline TFC- $138^{1}$ & $\begin{array}{l}\text { Volcán EI Ciego } \\
324680-3133067\end{array}$ & $\begin{array}{l}\text { Charcoal under phonotephrite } \\
\text { flow }\end{array}$ & AMS & $2600 \pm 160$ & $\begin{array}{l}2866 \text { to } 2366(2616 \pm 250) \\
917 \text { to } 417 \mathrm{BC}\end{array}$ \\
\hline TFC- $375^{2}$ & $\begin{array}{l}\text { Volcán El Ciego } \\
325786-3133070\end{array}$ & $\begin{array}{l}\text { Charcoal under phonotephrite } \\
\text { flow }\end{array}$ & AMS & $2660 \pm 40$ & $\begin{array}{l}2849 \text { to } 2739(2794 \pm 55) \\
900 \text { to } 790 \mathrm{BC}\end{array}$ \\
\hline TFC- $56^{1}$ & $\begin{array}{l}\text { Mña. de Chío } \\
332526-3125920\end{array}$ & $\begin{array}{l}\text { Charcoal under benmoreite } \\
\text { flow }\end{array}$ & AMS & $3620 \pm 140$ & $\begin{array}{l}4146 \text { to } 3721(3933 \pm 212) \\
2197 \text { to } 1772 \mathrm{BC}\end{array}$ \\
\hline TFC- $343^{2}$ & $\begin{array}{l}\text { Mña. Cueva del Ratón } \\
331169-3131360\end{array}$ & $\begin{array}{l}\text { Charcoal under mugearite } \\
\text { flow }\end{array}$ & Radiometric & $5370 \pm 50$ & 6290 to $6000(6145 \pm 145)$ \\
\hline TFC- $322^{2}$ & $\begin{array}{l}\text { Mña. Liferfe } \\
330460-3136360\end{array}$ & $\begin{array}{l}\text { Charcoal under mugearite } \\
\text { flow }\end{array}$ & AMS & $7400 \pm 40$ & 8330 to $8170(8250 \pm 80)$ \\
\hline TFC- $378^{2}$ & $\begin{array}{l}\text { Mña. del Banco } \\
324641-3133650\end{array}$ & Charcoal under basanite flow & AMS & $12,810 \pm 60$ & 15,370 to $14,910(15,140 \pm 230)$ \\
\hline \multicolumn{6}{|c|}{ NE RIFT ZONE } \\
\hline TFC-172 1 & $\begin{array}{l}\text { Pre-historic forest fire } \\
346735-3133430\end{array}$ & $\begin{array}{l}\text { Charcoal in red soil under } \\
\text { distal pumice fall }\end{array}$ & $\beta$-counting & $580 \pm 50$ & $\begin{array}{l}656 \text { to } 524(590 \pm 66) \\
1294 \text { to } 1426 \mathrm{AD}\end{array}$ \\
\hline TFC-178 ${ }^{1}$ & $\begin{array}{l}\text { Volcán del Portillo Upper Unit } \\
346699-3137920\end{array}$ & $\begin{array}{l}\text { Charcoal under phono- } \\
\text { tephrite flow }\end{array}$ & AMS & $11,080 \pm 160$ & 13,137 to $12,873(13,005 \pm 132)$ \\
\hline TFC-176 ${ }^{1}$ & $\begin{array}{l}\text { Volcán del Portillo Lower Unit } \\
345364-3134120\end{array}$ & $\begin{array}{l}\text { Charcoal under benmoreite } \\
\text { flow }\end{array}$ & AMS & $12,020 \pm 160$ & 14,052 to $13,725(13,888 \pm 163)$ \\
\hline TFC- $153^{1}$ & $\begin{array}{l}\text { Mña. Guamasa } \\
348746-3139150\end{array}$ & $\begin{array}{l}\text { Charcoal in thick soil under } \\
\text { basaltic flow }\end{array}$ & $\beta$-counting & $>33,000$ & - \\
\hline TFC-170 1 & $\begin{array}{l}\text { Mña. Cerrillar } \\
346290-3136790\end{array}$ & $\begin{array}{l}\text { Charcoal in thick soil under } \\
\text { basaltic flow }\end{array}$ & $\beta$-counting & $>33,000$ & - \\
\hline \multicolumn{6}{|c|}{ TEIDE-PICO VIEJO VOLCANIC COMPLEX } \\
\hline TFC- $05^{1}$ & $\begin{array}{l}\text { Latest eruption of Teide (Lavas } \\
\text { Negras) } 338330 / 3132420\end{array}$ & $\begin{array}{l}\text { Charcoal under phonolitic } \\
\text { flow }\end{array}$ & AMS & $1240 \pm 120$ & $\begin{array}{l}1290 \text { to } 1010(1150 \pm 140) \\
660 \text { to } 940 A D\end{array}$ \\
\hline TFC- $261^{2}$ & $\begin{array}{l}\text { Pico Viejo S flank evolved flows } \\
324880-3124630\end{array}$ & Charcoal under lava flow & AMS & $14,630 \pm 50$ & 17,890 to $17,160(17,525 \pm 365)$ \\
\hline TFC-20 ${ }^{1}$ & $\begin{array}{l}\text { Pico Viejo N flank intermediate } \\
\text { flows } 334373-3140511\end{array}$ & $\begin{array}{l}\text { Charcoal under phonolitic } \\
\text { flow }\end{array}$ & AMS & $17,570 \pm 150$ & 21,097 to $20,454(20,775 \pm 321)$ \\
\hline TFC-139 ${ }^{1}$ & $\begin{array}{l}\text { Pico Viejo N flank basaltic flows } \\
331937-3139850\end{array}$ & Charcoal under basaltic flow & AMS & $27,030 \pm 430$ & - \\
\hline TFC- $167^{1}$ & $\begin{array}{l}\text { Old Teide phonolites, Orotava } \\
\text { Valley } 345809-3137140\end{array}$ & $\begin{array}{l}\text { Charcoal under phonolitic } \\
\text { flow }\end{array}$ & AMS & $32,360 \pm 800$ & - \\
\hline \multicolumn{6}{|c|}{ PERIPHERAL DOMES OF THE TEIDE-PICO VIEJO VOLCANIC COMPLEX } \\
\hline TFC- $25^{1}$ & $\begin{array}{l}\text { Roques Blancos } \\
332782-3135640\end{array}$ & $\begin{array}{l}\text { Charcoal under phonolite } \\
\text { flow }\end{array}$ & AMS & $1790 \pm 120$ & $\begin{array}{l}1865 \text { to } 1563(1714 \pm 151) \\
85 \text { to } 387 \mathrm{AD}\end{array}$ \\
\hline TFC-38 ${ }^{1}$ & $\begin{array}{l}\text { Early Roques Blancos } \\
332498-3140540\end{array}$ & $\begin{array}{l}\text { Charcoal under phonolite } \\
\text { flow }\end{array}$ & AMS & $2010 \pm 120$ & $\begin{array}{l}2122 \text { to } 1827(1974 \pm 147) \\
173 \mathrm{BC} \text { to } 123 \mathrm{AD}\end{array}$ \\
\hline TFC- $02^{1}$ & $\begin{array}{l}\text { Mña. Blanca pumice ? } \\
339305-3133180\end{array}$ & Charcoal under pumice fall & AMS & $2020 \pm 140$ & $\begin{array}{l}2151 \text { to } 1821(1986 \pm 165) \\
202 B C \text { to } 129 A D\end{array}$ \\
\hline TFC- $15^{1}$ & $\begin{array}{l}\text { El Boquerón } \\
335220-3131440\end{array}$ & $\begin{array}{l}\text { Charcoal in red soil under } \\
\text { pumice }\end{array}$ & AMS & $2420 \pm 140$ & $\begin{array}{l}2713 \text { to } 2343(2528 \pm 185) \\
764 \text { to } 394 \mathrm{BC}\end{array}$ \\
\hline TFC- $01^{1}$ & $\begin{array}{l}\text { La Abejera Baja } \\
339981-3133510\end{array}$ & $\begin{array}{l}\text { Charcoal under phonolite } \\
\text { flow }\end{array}$ & AMS & $4790 \pm 140$ & 5647 to $5324(5486 \pm 162)$ \\
\hline CITF- $60^{1}$ & $\begin{array}{l}\text { La Abejera Alta } \\
340596-3133780\end{array}$ & Charcoal under phonolite flow & AMS & $5170 \pm 110$ & 6175 to $5647(5911 \pm 264)$ \\
\hline TFC-181 & $\begin{array}{l}\text { Mña. Negra-Los Tomillos } \\
340110-3137680\end{array}$ & Charcoal under phonolite flow & AMS & $8220 \pm 120$ & 9400 to $9021(9210 \pm 190)$ \\
\hline
\end{tabular}

\footnotetext{
${ }^{1}$ Laboratoire des Sciences du Climat et de l'Environnement, CEA-CNRS, France $\quad{ }^{2}$ Beta Analytic Radiocarbon Dating Laboratory, USA.
} 
Table 2. K-Ar ages from samples of the Teide, Pico Viejo Volcanoes and the NW and NE rift zones of Tenerife. Age calculations are based on the decay and abundance constants from Steiger and Jäger (1977). The weighted mean 40A $r^{*}$ values from the replicate experiments are used in the final age calculation.

\begin{tabular}{|c|c|c|c|c|c|c|c|}
\hline Sample & Location & UTM & $\begin{array}{l}\text { Weight molten } \\
(\mathrm{g})\end{array}$ & $\begin{array}{c}\mathrm{K}^{*} \\
(\mathrm{wt.} \%)\end{array}$ & $\operatorname{Ar}^{40}(\%)$ & $\begin{array}{l}\operatorname{Ar}^{*}\left(10^{-12}\right. \\
\mathrm{mol} / \mathrm{g}) \pm 1 \sigma\end{array}$ & $\begin{array}{c}\text { Age } \pm 2 \sigma \\
\text { ka }\end{array}$ \\
\hline \multicolumn{8}{|c|}{ NE RIFT ZONE } \\
\hline CITF-99 & $\begin{array}{l}\text { Volcán del Portillo (dated } \\
{ }^{14} \mathrm{C} \text { TFC 178) }\end{array}$ & $346.75 / 3.137 .9$ & $\begin{array}{l}1.84000 \\
3.15460\end{array}$ & $\begin{array}{l}1.486 \pm 0.015 \\
" \ldots \ldots \ldots \ldots \ldots . "\end{array}$ & $\begin{array}{l}0.267 \\
0.255\end{array}$ & $\begin{array}{l}0.022 \pm 0.009 \\
0.018 \pm 0.006\end{array}$ & $8 \pm 4$ \\
\hline CITF-15 & Mña. de Enmedio & $349.94 / 3.131 .9$ & $\begin{array}{l}1.38104 \\
2.09397\end{array}$ & $\begin{array}{l}1.577 \pm 0.016 \\
" \ldots \ldots \ldots \ldots \ldots . .\end{array}$ & $\begin{array}{l}0.656 \\
0.917\end{array}$ & $\begin{array}{l}0.083 \pm 0.006 \\
0.089 \pm 0.005\end{array}$ & $31 \pm 3$ \\
\hline CITF-18 & Mña. de Guamasa & $346.66 / 3.133 .3$ & $\begin{array}{l}1.98317 \\
2.14727\end{array}$ & $\begin{array}{l}1.527 \pm 0.015 \\
" \ldots \ldots \ldots \ldots \ldots . .\end{array}$ & $\begin{array}{l}0.405 \\
0.778\end{array}$ & $\begin{array}{l}0.087 \pm 0.005 \\
0.088 \pm 0.005\end{array}$ & $33 \pm 3$ \\
\hline CITF-16 & Mña. del Cerrillar & $348.47 / 3.132 .1$ & $\begin{array}{l}1.77942 \\
1.90060\end{array}$ & $\begin{array}{l}1.395 \pm 0.014 \\
" \ldots \ldots \ldots \ldots . . . "\end{array}$ & $\begin{array}{l}0.671 \\
0.595\end{array}$ & $\begin{array}{l}0.085 \pm 0.005 \\
0.093 \pm 0.005\end{array}$ & $37 \pm 3$ \\
\hline CITF-26 & Aut. Sur Km/ 30.8 & $362.39 / 3.125 .2$ & $\begin{array}{l}1.52818 \\
1.48840\end{array}$ & $\begin{array}{l}1.262 \pm 0.013 \\
" \ldots \ldots \ldots \ldots \ldots . "\end{array}$ & $\begin{array}{l}2.547 \\
1.840\end{array}$ & $\begin{array}{l}0.670 \pm 0.007 \\
0.688 \pm 0.009\end{array}$ & $309 \pm 8$ \\
\hline CITF-12 & Izaña & $353.43 / 3.133 .3$ & $\begin{array}{l}1.33043 \\
1.17201\end{array}$ & $\begin{array}{l}1.527 \pm 0.015 \\
" \ldots \ldots \ldots \ldots \ldots . .\end{array}$ & $\begin{array}{l}6.397 \\
8.144\end{array}$ & $\begin{array}{l}1.370 \pm 0.010 \\
1.346 \pm 0.011\end{array}$ & $513 \pm 12$ \\
\hline CITF-88 & El Caletón & $357.42 / 3.149 .1$ & $\begin{array}{l}1.31866 \\
2.12823\end{array}$ & $\begin{array}{l}1.337 \pm 0.013 \\
" \ldots \ldots \ldots \ldots \ldots . "\end{array}$ & $\begin{array}{l}12.550 \\
9.994\end{array}$ & $\begin{array}{l}1.574 \pm 0.012 \\
1.635 \pm 0.010\end{array}$ & $694 \pm 15$ \\
\hline CITF-23 & Mña. Birmagen & $368.26 / 3.142 .0$ & $\begin{array}{l}1.98025 \\
2.03956\end{array}$ & $\begin{array}{l}1.810 \pm 0.018 \\
" \ldots \ldots \ldots \ldots . . . "\end{array}$ & $\begin{array}{l}9.883 \\
12.606\end{array}$ & $\begin{array}{l}2.474 \pm 0.014 \\
2.478 \pm 0.013\end{array}$ & $789 \pm 17$ \\
\hline \multicolumn{8}{|c|}{ SOUTH RIFT ZONE } \\
\hline CITF-28 & La Buzanada & $337.10 / 3.108 .2$ & $\begin{array}{l}1.88896 \\
2.15493\end{array}$ & $\begin{array}{l}1.237 \pm 0.012 \\
" \ldots \ldots \ldots \ldots . . .\end{array}$ & $\begin{array}{l}1.505 \\
1.014\end{array}$ & $\begin{array}{l}0.195 \pm 0.010 \\
0.211 \pm 0.006\end{array}$ & $96 \pm 5$ \\
\hline CITF-30 & Mña. Gorda & $333.44 / 3.100 .9$ & $\begin{array}{l}2.18102 \\
2.14499\end{array}$ & $\begin{array}{l}1.004 \pm 0.010 \\
" \ldots \ldots \ldots \ldots . . "\end{array}$ & $\begin{array}{l}3.610 \\
2.992\end{array}$ & $\begin{array}{l}0.553 \pm 0.005 \\
0.568 \pm 0.005\end{array}$ & $322 \pm 8$ \\
\hline CITF-29 & Mña. de Guaza & $332.33 / 3.101 .6$ & $\begin{array}{l}1.60821 \\
1.51517\end{array}$ & $\begin{array}{l}4.118 \pm 0.041 \\
" \ldots \ldots \ldots \ldots . . . "\end{array}$ & $\begin{array}{l}24.483 \\
21.805\end{array}$ & $\begin{array}{l}6.643 \pm 0.034 \\
6.583 \pm 0.033\end{array}$ & $926 \pm 20$ \\
\hline \multicolumn{8}{|c|}{ NW RIFT ZONE (DISTAL PART) } \\
\hline TFC-573 & Volcán del Palmar & $320.407 / 3.139 .2$ & $\begin{array}{l}1.05197 \\
2.10684\end{array}$ & $\begin{array}{l}1.328 \pm 0.013 \\
" \ldots \ldots \ldots \ldots \ldots . "\end{array}$ & $\begin{array}{l}3.846 \\
5.031\end{array}$ & $\begin{array}{l}0.334 \pm 0.010 \\
0.361 \pm 0.006\end{array}$ & $153 \pm 6$ \\
\hline TFC-571 & Volcán Teno Alto & $311.850 / 3.138 .3$ & $\begin{array}{l}1.03751 \\
1.93700\end{array}$ & $\begin{array}{l}1.569 \pm 0.016 \\
" \ldots \ldots \ldots \ldots . . .\end{array}$ & $\begin{array}{l}2.323 \\
5.101\end{array}$ & $\begin{array}{l}0.451 \pm 0.013 \\
0.495 \pm 0.007\end{array}$ & $178 \pm 6$ \\
\hline TFC-569 & Mña. Los Silos & 321.3253 .140 .4 & $\begin{array}{l}1.27816 \\
1.08304\end{array}$ & $\begin{array}{l}1.577 \pm 0.016 \\
" \ldots \ldots \ldots \ldots \ldots . .\end{array}$ & $\begin{array}{l}2.762 \\
3.314\end{array}$ & $\begin{array}{l}0.512 \pm 0.013 \\
0.547 \pm 0.012\end{array}$ & $194 \pm 8$ \\
\hline TFC-574 & $\begin{array}{l}\text { Volcán Tierra del } \\
\text { Trigo }\end{array}$ & $323.200 / 3.138 .7$ & $\begin{array}{l}1.22597 \\
1.13251\end{array}$ & $\begin{array}{l}1.826 \pm 0.018 \\
" \ldots \ldots \ldots \ldots \ldots . .\end{array}$ & $\begin{array}{l}6.333 \\
3.245\end{array}$ & $\begin{array}{l}0.786 \pm 0.011 \\
0.874 \pm 0.011\end{array}$ & $261 \pm 7$ \\
\hline TFC-558 & $\begin{array}{l}\text { Upper flow, western } \\
\text { rim of Icod Valley }\end{array}$ & $331.004 / 3.138 .0$ & $\begin{array}{l}1.11669 \\
1.44401\end{array}$ & $\begin{array}{l}1.644 \pm 0.016 \\
" \ldots \ldots \ldots \ldots \ldots . .\end{array}$ & $\begin{array}{l}6.145 \\
4.473\end{array}$ & $\begin{array}{l}1.194 \pm 0.011 \\
1.152 \pm 0.011\end{array}$ & $411 \pm 10$ \\
\hline TFC-570 & Mña. de Taco & $321.100 / 3.141 .4$ & $\begin{array}{l}0.95023 \\
1.44732\end{array}$ & $\begin{array}{l}3.702 \pm 0.037 \\
" \ldots \ldots \ldots \ldots \ldots . .\end{array}$ & $\begin{array}{l}29.554 \\
43.764\end{array}$ & $\begin{array}{l}4.463 \pm 0.026 \\
4.598 \pm 0.024\end{array}$ & $706 \pm 15$ \\
\hline TFC-564 & $\begin{array}{l}\text { Playa de la Arena } \\
\text { (S flank, NW rift zone) }\end{array}$ & $319.502 / 3.124 .73$ & $\begin{array}{l}1.09534 \\
1.20229\end{array}$ & $\begin{array}{l}1.569 \pm 0.016 \\
" \ldots \ldots \ldots \ldots . . .\end{array}$ & $\begin{array}{l}6.779 \\
8.809\end{array}$ & $\begin{array}{l}2.400 \pm 0.017 \\
2.502 \pm 0.016\end{array}$ & $901 \pm 20$ \\
\hline TFC-559 & $\begin{array}{l}\text { Lower flow of the W. } \\
\text { rim of the Icod Valley }\end{array}$ & $331.588 / 3.137 .8$ & $\begin{array}{l}1.19247 \\
1.37110\end{array}$ & $\begin{array}{l}2.100 \pm 0.021 \\
" \ldots \ldots \ldots \ldots \ldots . .\end{array}$ & $\begin{array}{l}43.291 \\
30.003\end{array}$ & $\begin{array}{l}4.134 \pm 0.023 \\
4.272 \pm 0.023\end{array}$ & $1153 \pm 25$ \\
\hline \multicolumn{8}{|c|}{ TEIDE-PICO VIEJO VOLCANIC COMPLEX } \\
\hline CITF-301 & $\begin{array}{l}\text { Phonolitic flow of } \\
\text { Playa San Marco }\end{array}$ & $346.99 / 3.137 .9$ & $\begin{array}{l}1.71730 \\
1.65063\end{array}$ & $\begin{array}{l}4.284 \pm 0.043 \\
\text { "............" }\end{array}$ & $\begin{array}{l}2.351 \\
1.612\end{array}$ & $\begin{array}{l}0.243 \pm 0.009 \\
0.221 \pm 0.011\end{array}$ & $32 \pm 1$ \\
\hline CITF-98 & $\begin{array}{l}\text { Old Teide phonolites } \\
\text { inside the Orotava valley }\end{array}$ & $345.81 / 3.137 .1$ & $\begin{array}{l}2.02239 \\
2.41121\end{array}$ & $\begin{array}{l}3.777 \pm 0.038 \\
" \ldots \ldots \ldots \ldots \ldots .\end{array}$ & $\begin{array}{l}3.366 \\
4.395\end{array}$ & $\begin{array}{l}0.230 \pm 0.009 \\
0.207 \pm 0.007\end{array}$ & $33 \pm 2$ \\
\hline CITF-85 & $\begin{array}{l}\text { Old Teide flows, base of } \\
\text { cliff of Playa San Marcos }\end{array}$ & $331.13 / 3.140 .3$ & $\begin{array}{l}1.07373 \\
1.60741\end{array}$ & $\begin{array}{l}1.544 \pm 0.015 \\
\text { " } \ldots \ldots \ldots \ldots \ldots . .\end{array}$ & $\begin{array}{l}2.090 \\
1.311\end{array}$ & $\begin{array}{l}0.215 \pm 0.092 \\
0.244 \pm 0.006\end{array}$ & $88 \pm 4$ \\
\hline CITF-84 & $\begin{array}{l}\text { Old Teide flows, base of } \\
\text { cliff of Playa Sto Domingo }\end{array}$ & $335.91 / 3.142 .0$ & $\begin{array}{l}1.38494 \\
2.00200\end{array}$ & $\begin{array}{l}1.610 \pm 0.016 \\
" \ldots \ldots \ldots \ldots \ldots . "\end{array}$ & $\begin{array}{l}3.241 \\
2.900\end{array}$ & $\begin{array}{l}0.338 \pm 0.007 \\
0.349 \pm 0.005\end{array}$ & $124 \pm 4$ \\
\hline \multicolumn{8}{|c|}{ GALERIA SALTO DEL FRONTON (see figure 4 for details) } \\
\hline $10 \mathrm{GSF}$ & $2700 \mathrm{~m}$ & - & $\begin{array}{l}1.65487 \\
2.33548\end{array}$ & $\begin{array}{l}1.503 \pm 0.015 \\
" \ldots \ldots \ldots \ldots . . "\end{array}$ & $\begin{array}{l}4.477 \\
3.408\end{array}$ & $\begin{array}{l}0.525 \pm 0.008 \\
0.513 \pm 0.005\end{array}$ & $198 \pm 5$ \\
\hline 14 GSF & $1500 \mathrm{~m}$ & - & $\begin{array}{l}1.43489 \\
2.22959\end{array}$ & $\begin{array}{l}1.677 \pm 0.017 \\
\text { “..........." }\end{array}$ & $\begin{array}{l}2.909 \\
2.939\end{array}$ & $\begin{array}{l}0.316 \pm 0.007 \\
0.323 \pm 0.005\end{array}$ & $110 \pm 4$ \\
\hline 15 GSF & $1100 \mathrm{~m}$ & - & $\begin{array}{l}2.14574 \\
2.18357\end{array}$ & $\begin{array}{l}3.179 \pm 0.032 \\
" \ldots \ldots \ldots \ldots \ldots . . "\end{array}$ & $\begin{array}{l}5.233 \\
4.503\end{array}$ & $\begin{array}{l}0.656 \pm 0.006 \\
0.644 \pm 0.007\end{array}$ & $118 \pm 3$ \\
\hline
\end{tabular}


Table 3. Volume and eruptive rate estimates for the different main units of the latest volcanic phase of Tenerife, the Teide volcanic complex and the NW and NE rift zones

\begin{tabular}{|c|c|c|c|c|c|c|c|}
\hline & Volcanic unit & $\begin{array}{l}\text { Composition }\left(\mathrm{SiO}_{2}\right. \\
\text { range of products) }\end{array}$ & $\begin{array}{l}\text { Age range of } \\
\text { activity (k.y.) }\end{array}$ & $\begin{array}{l}\text { Duration } \\
\text { (k.y.) }\end{array}$ & $\begin{array}{c}\text { Average } \\
\text { thickness (m) }\end{array}$ & $\begin{array}{c}\text { Volume } \\
\left(\mathrm{km}^{3}\right)\end{array}$ & $\begin{array}{l}\text { Average } \\
\text { eruptive } \\
\text { rate } \\
\left(\mathrm{km}^{3} / \mathrm{k} . \mathrm{y} .\right) \\
\end{array}$ \\
\hline \multirow{4}{*}{ NW RIFT ZONE } & $\begin{array}{l}\text { Holocene basic } \\
\text { eruptions }\end{array}$ & $\begin{array}{c}39-52 \\
\text { (basaltic and } \\
\text { intermediate) }\end{array}$ & $10-0$ & 10 & 80 & 8 & 0.8 \\
\hline & $\begin{array}{l}\text { Holocene felsic } \\
\text { eruptions }\end{array}$ & $\begin{array}{c}53-59 \\
\text { (evolved and } \\
\text { phonolitic) }\end{array}$ & $6-1$ & 5 & 10 & 2 & 0.4 \\
\hline & $\begin{array}{l}\text { Pleistocene } \\
\text { postcollapse } \\
\text { eruptions }\end{array}$ & $\begin{array}{c}43-45 \\
\text { (basaltic) }\end{array}$ & $194-10$ & 184 & 120 & 22 & 0.1 \\
\hline & Average NW Rift & $39-59$ & $200-0$ & 200 & 200 & 32 & 0.4 \\
\hline NE RIFT ZONE & $\begin{array}{l}\text { Upper Pleistocene } \\
\text { Post-collapse } \\
\text { eruptions }\end{array}$ & $\begin{array}{c}43-57 \\
\text { (basaltic, } \\
\text { intermediate and } \\
\text { evolved) }\end{array}$ & $37-0$ & 37 & 80 & 9 & 0.2 \\
\hline \multirow{7}{*}{$\frac{\frac{\text { CENTRAL }}{\text { VOLCANIC }}}{\underline{\text { COMPLEX }}}$} & $\begin{array}{l}\text { Initial filling of the } \\
\text { collapse } \\
\text { embayment }\end{array}$ & $\begin{array}{c}44-46 \\
\text { (basaltic) }\end{array}$ & $200-150$ & 50 & 350 & 62 & 1.2 \\
\hline & Old Teide & $\begin{array}{l}\text { 45-48 } \\
\text { (intermediate, } \\
\text { evolved and } \\
\text { phonolitic) }\end{array}$ & $150-30$ & 120 & 260 & 70 & 0.6 \\
\hline & Pico Viejo Volcano & $\begin{array}{l}49-59 \\
\text { (intermediate, } \\
\text { evolved and } \\
\text { phonolitic) }\end{array}$ & $30-15$ & 15 & 160 & 15 & 1 \\
\hline & $\begin{array}{l}\text { Peripheral lava } \\
\text { domes }\end{array}$ & $\begin{array}{c}52-61 \\
\text { (evolved and } \\
\text { phonolitic) }\end{array}$ & $10-2$ & 8 & 50 & 6,5 & 0.8 \\
\hline & $\begin{array}{l}\text { Teide stratocone } \\
\text { (since } 30 \text { k.y. BP) }\end{array}$ & $\begin{array}{c}60 \\
\text { (phonolitic) }\end{array}$ & $30-0$ & 30 & 60 & 0.7 & 0.02 \\
\hline & $\begin{array}{l}\text { Average CVC } \\
\text { including early } \\
\text { phases of filling of } \\
\text { the collapse } \\
\text { embayment }\end{array}$ & $44-61$ & $200-1$ & 200 & 880 & 160 & 0.8 \\
\hline & $\begin{array}{l}\text { Average CVC } \\
\text { excluding early } \\
\text { phases of filling of } \\
\text { the collapse } \\
\text { embayment }\end{array}$ & $45-61$ & $150-1$ & 150 & 550 & 98 & 0.6 \\
\hline
\end{tabular}




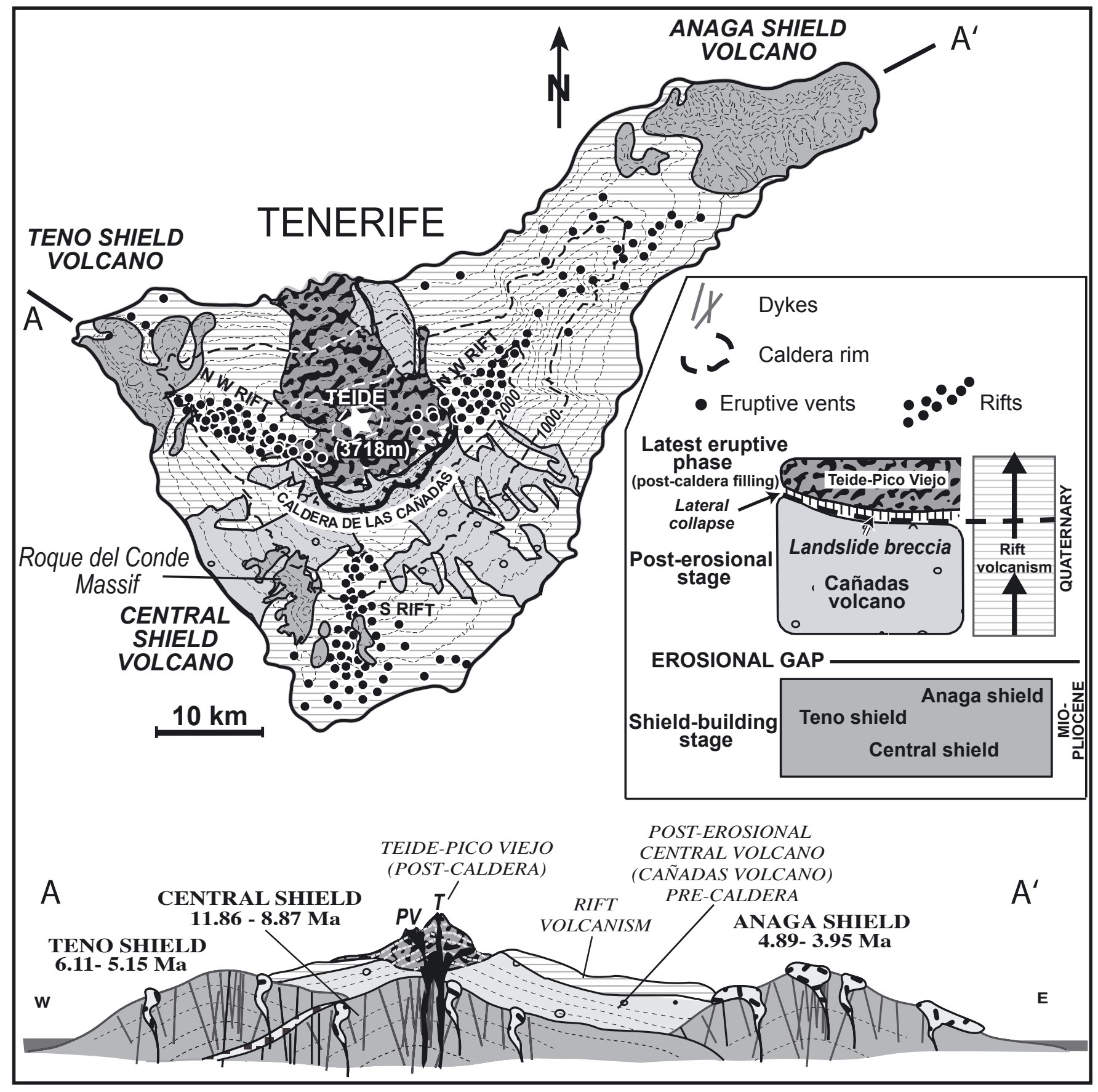




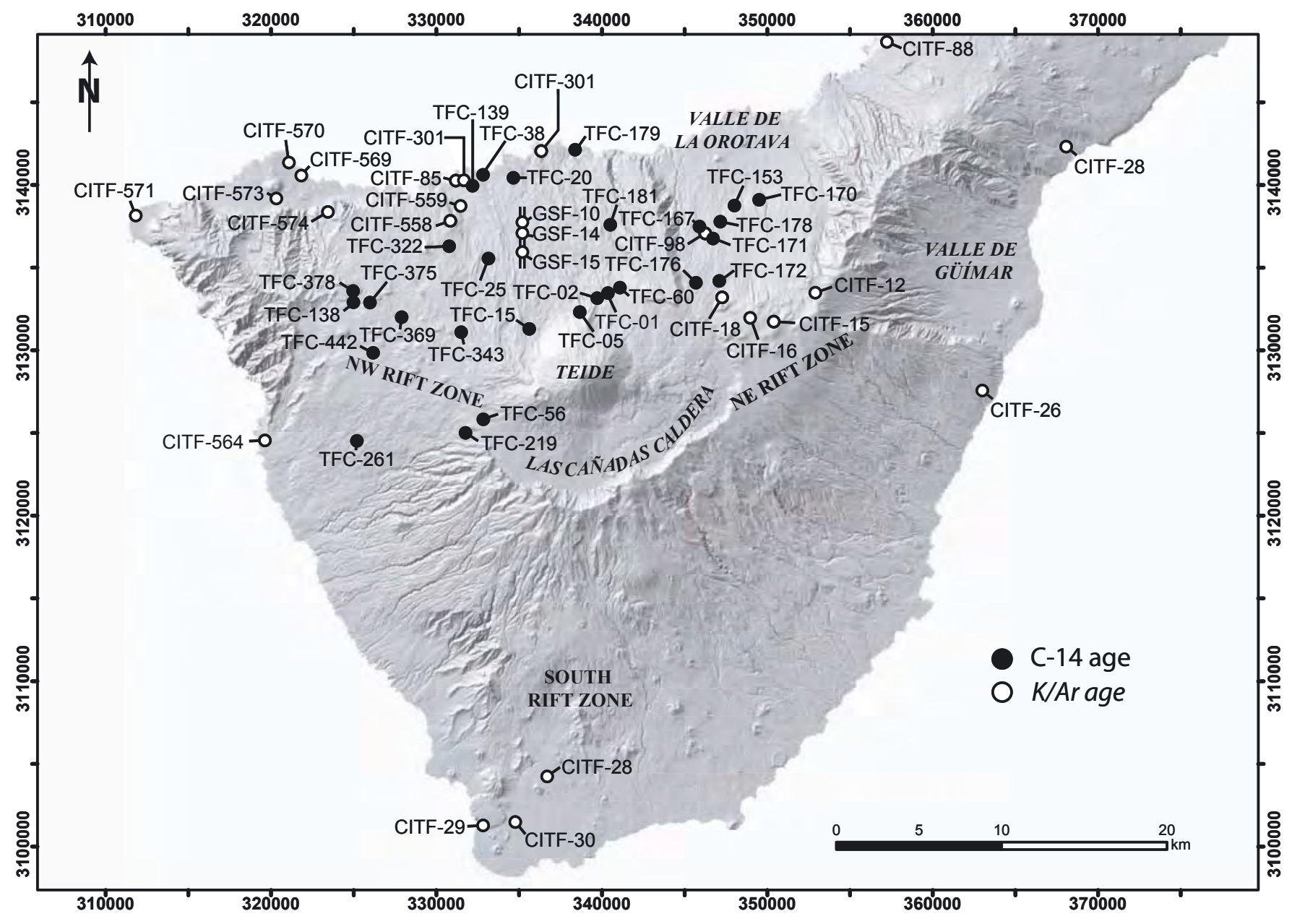




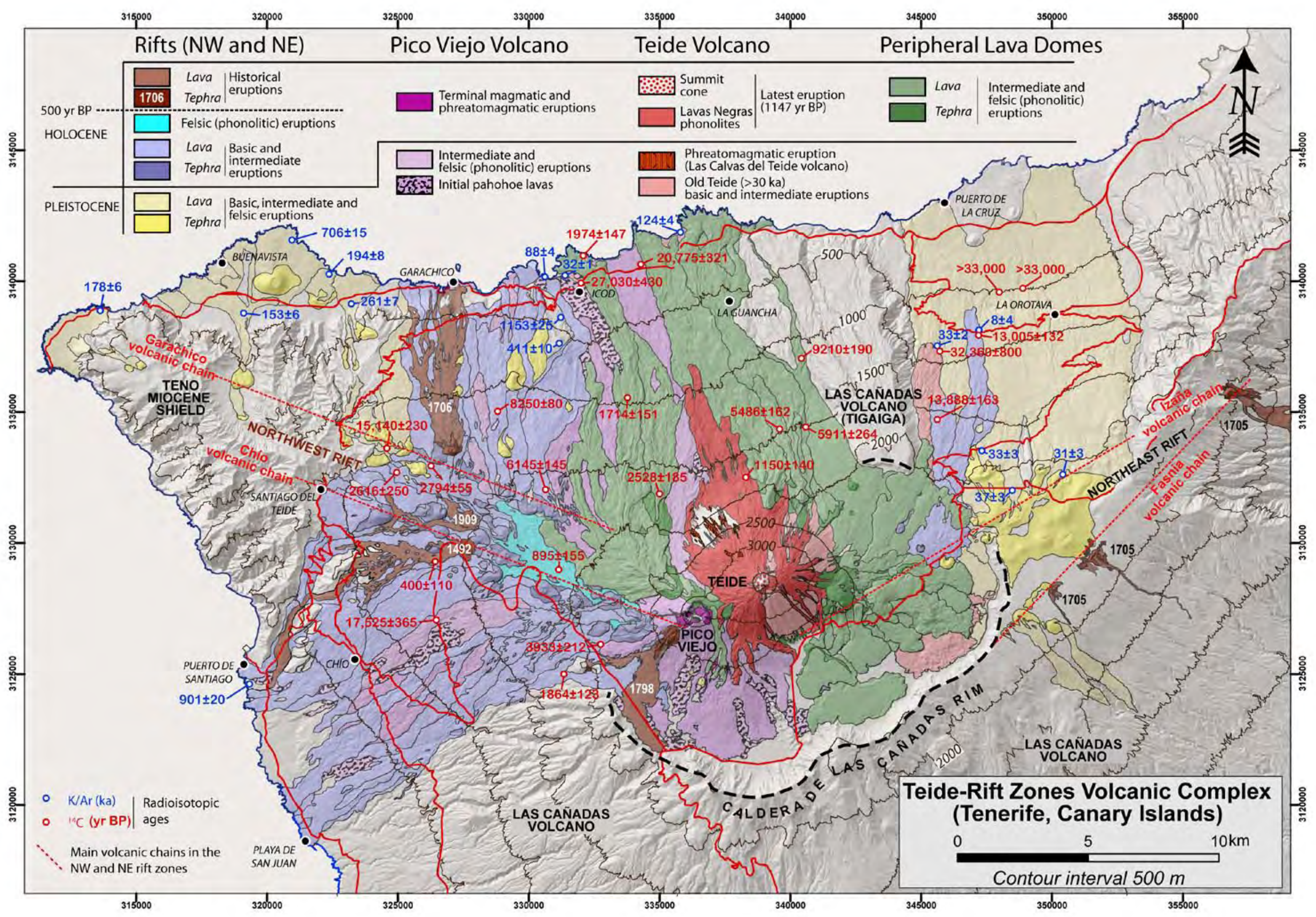




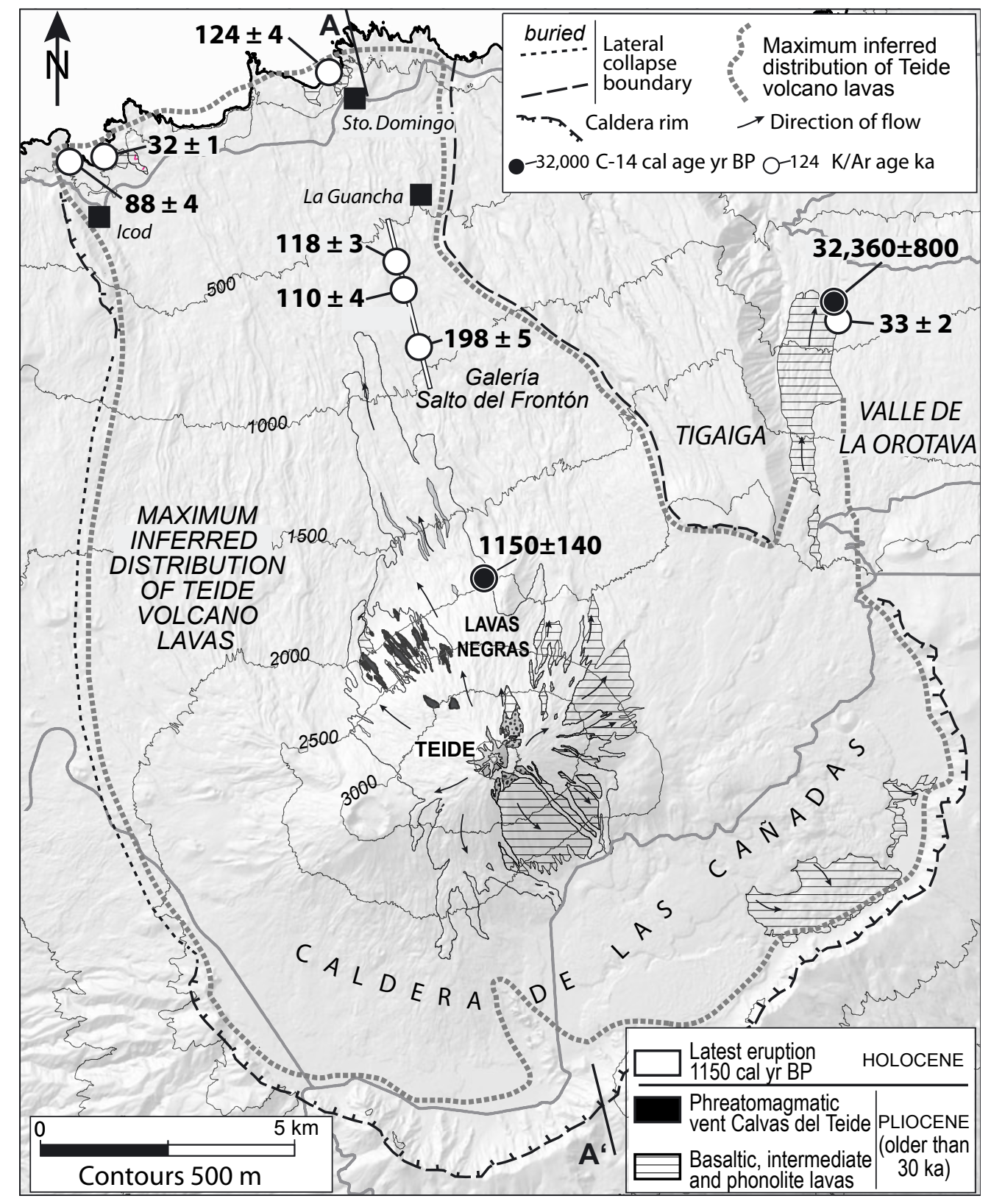

\section{A}

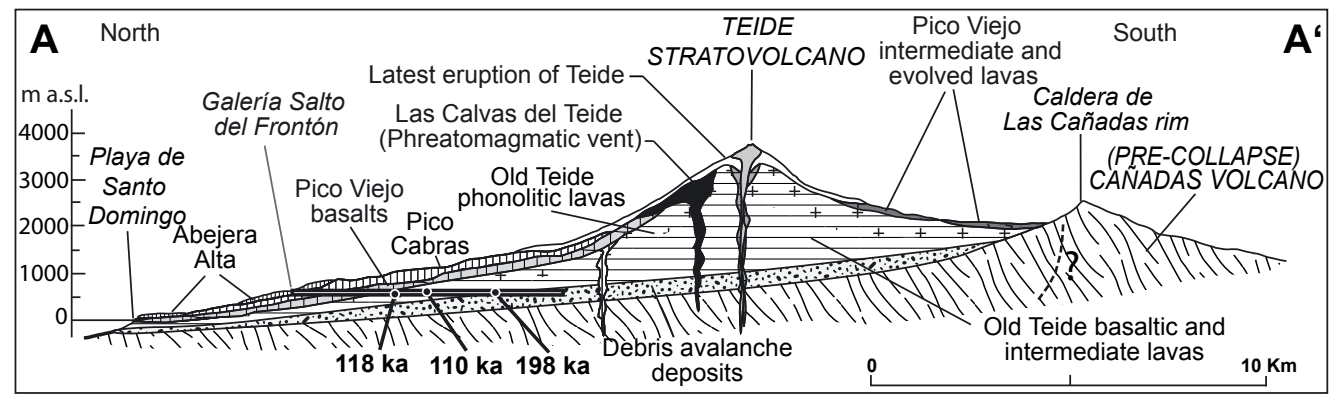

\section{B}

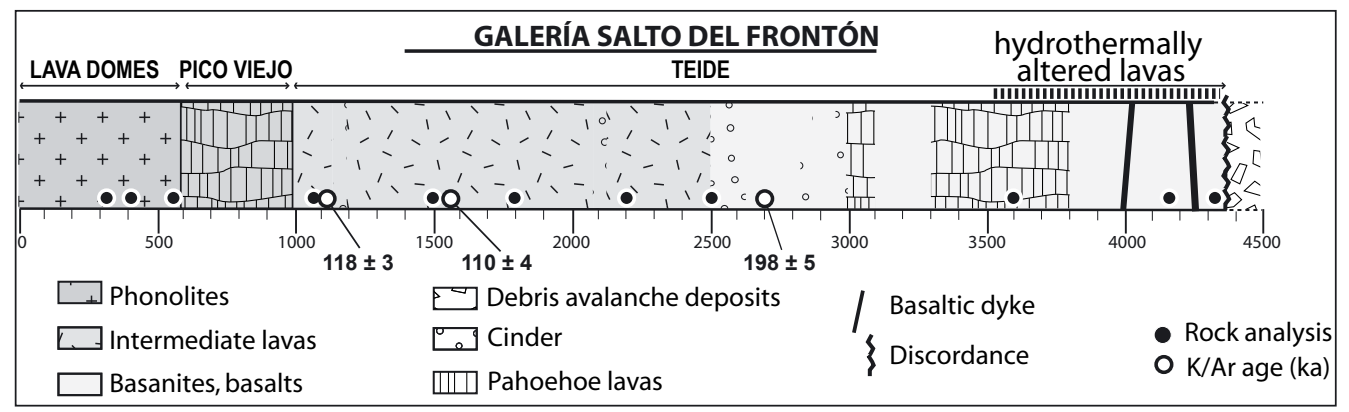



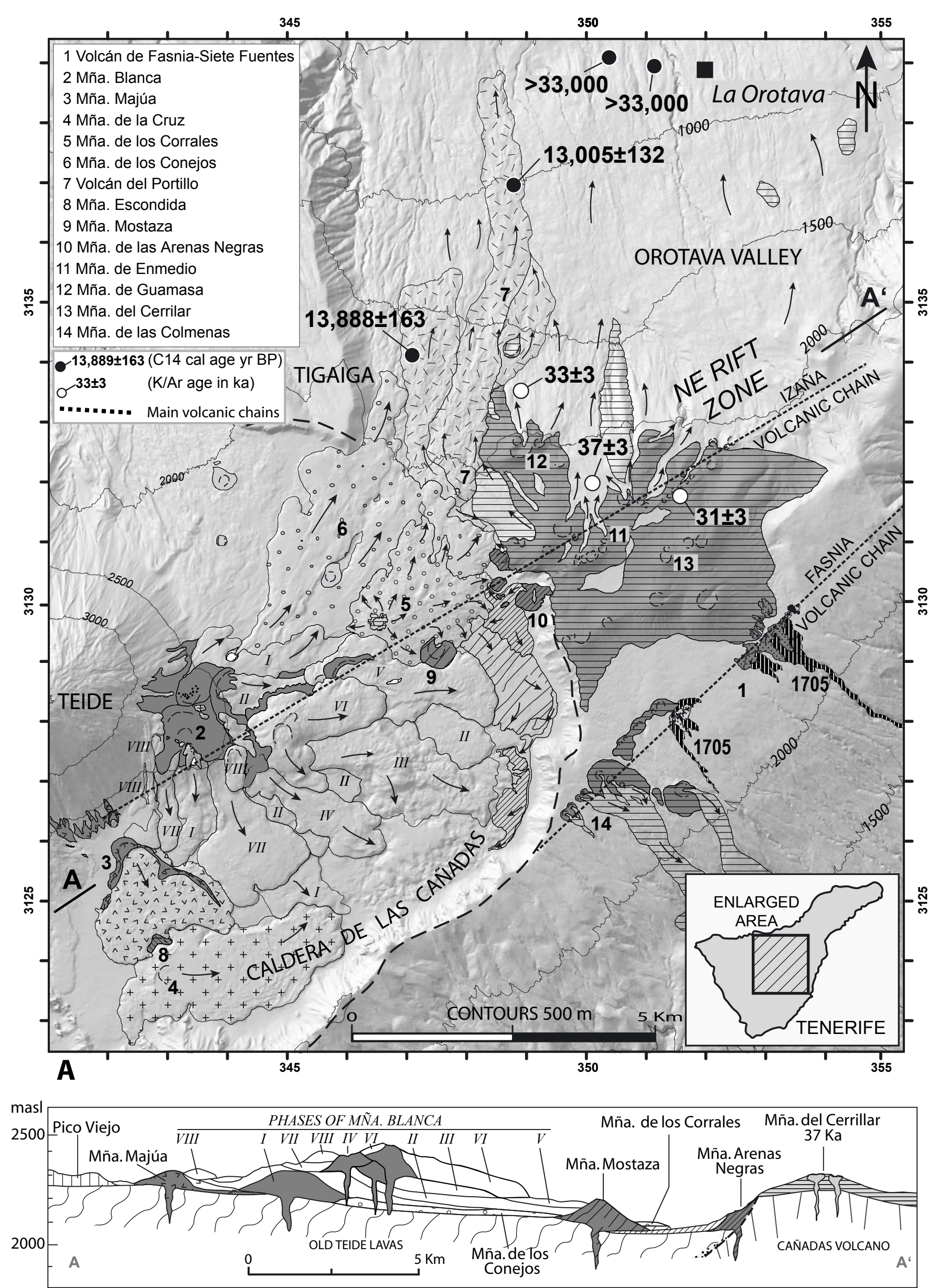

B 


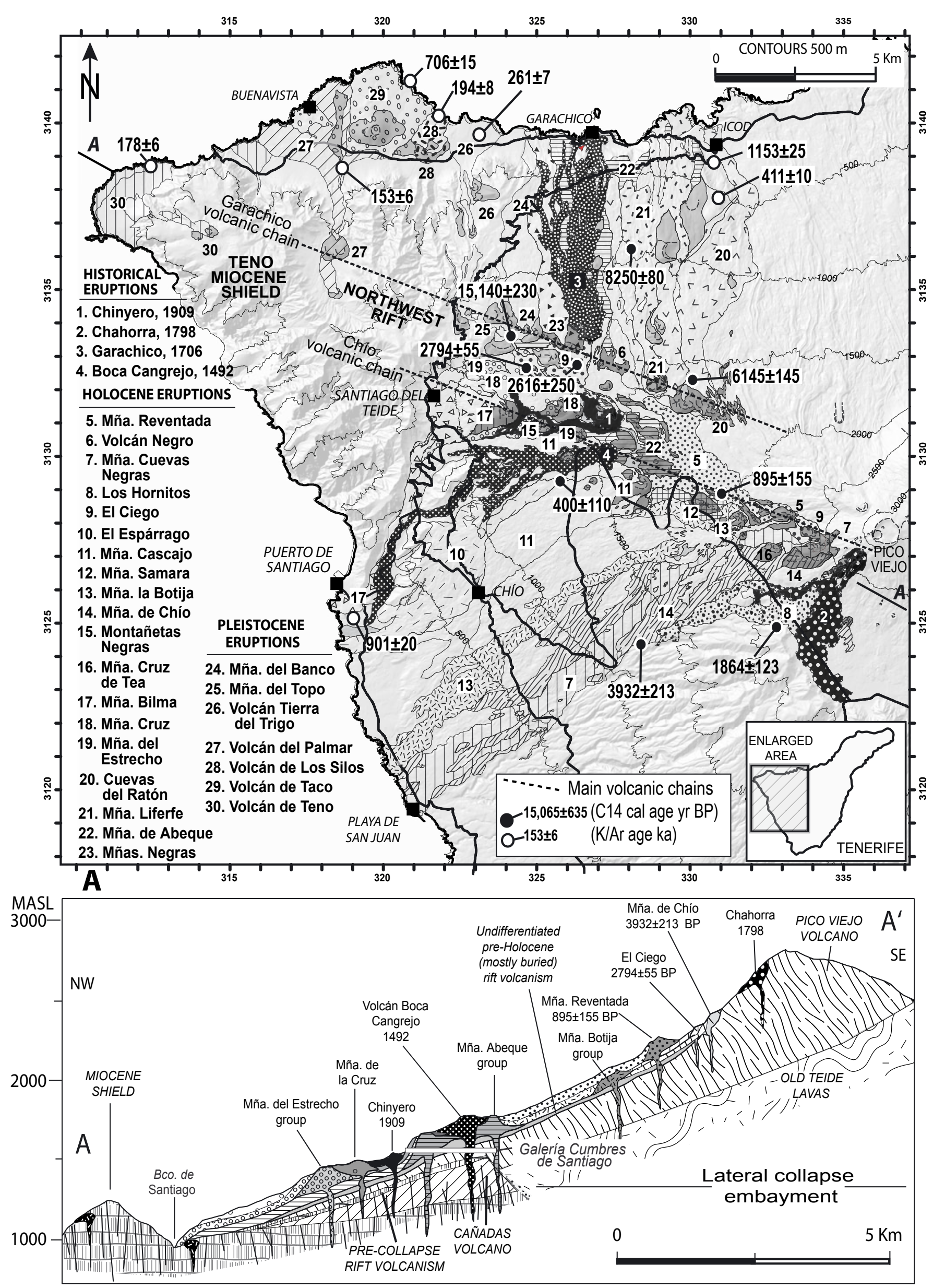

B 


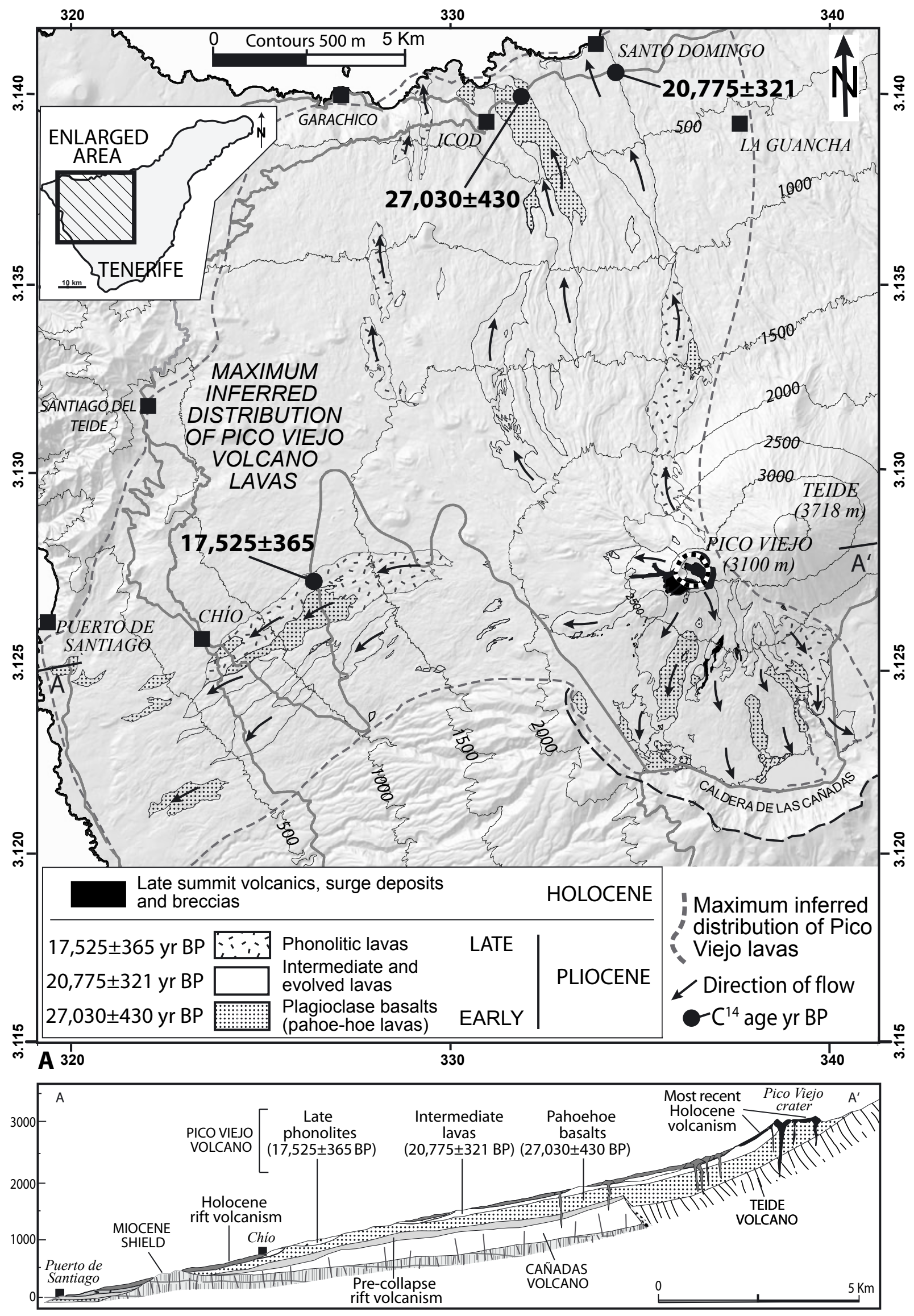

B 


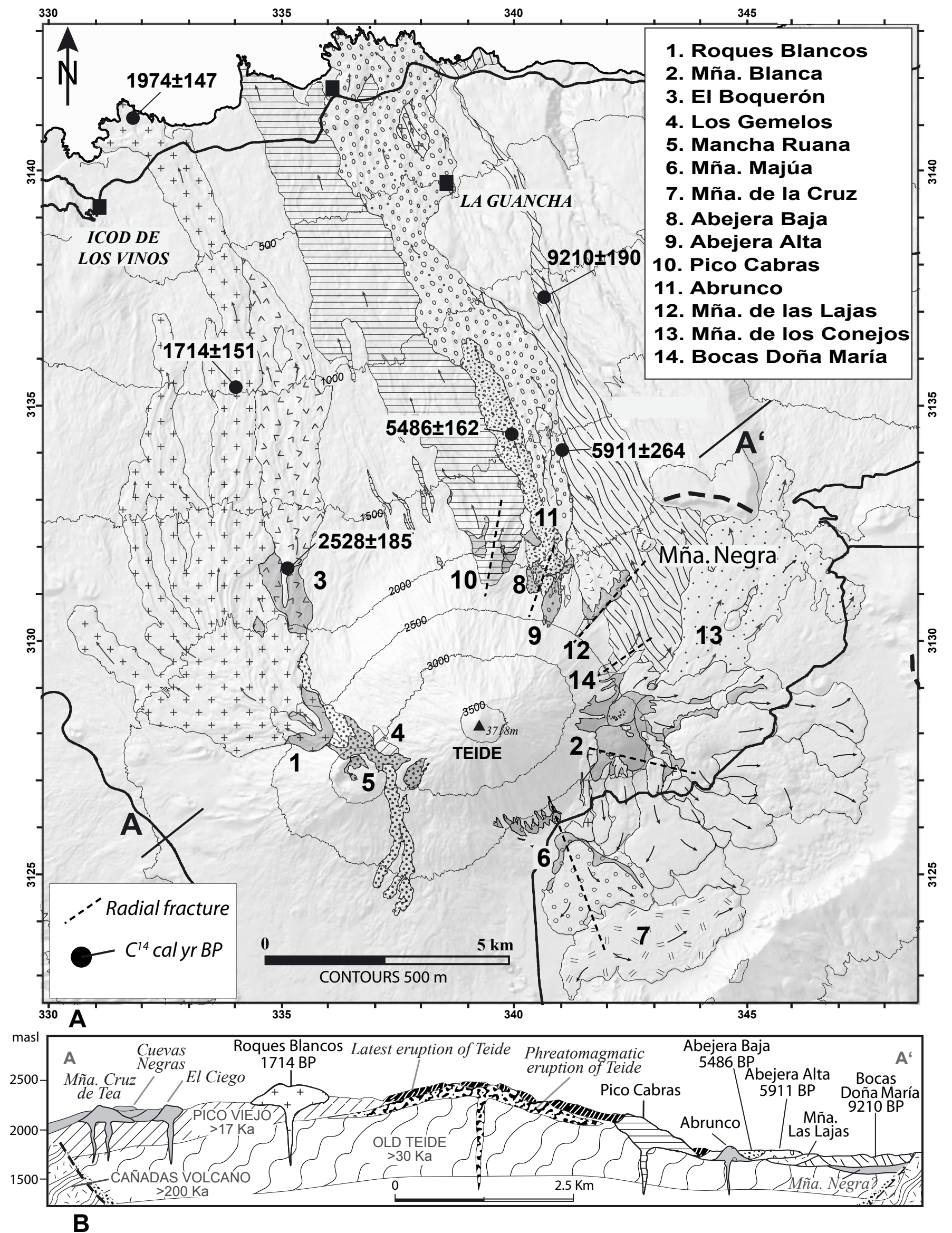




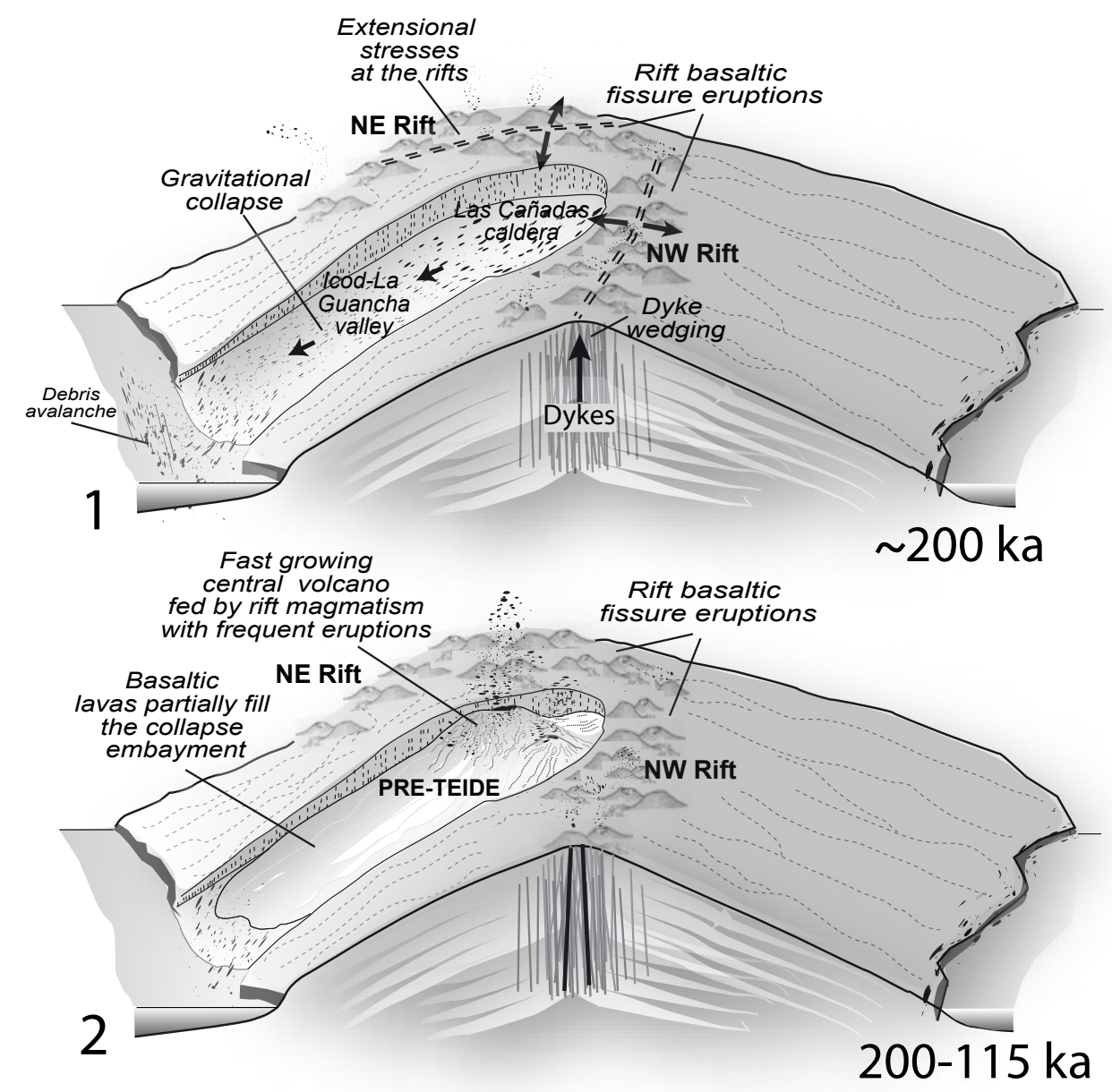

As the central volcano developed,

less frequent eruptions and

longer residence times allow

differentiation of rift magmas

in shallow reservoirs

Intermediate
(trachybasaltic)
lavas predominate

at this stage

Rift basaltic
fissure eruptions fissure eruptions

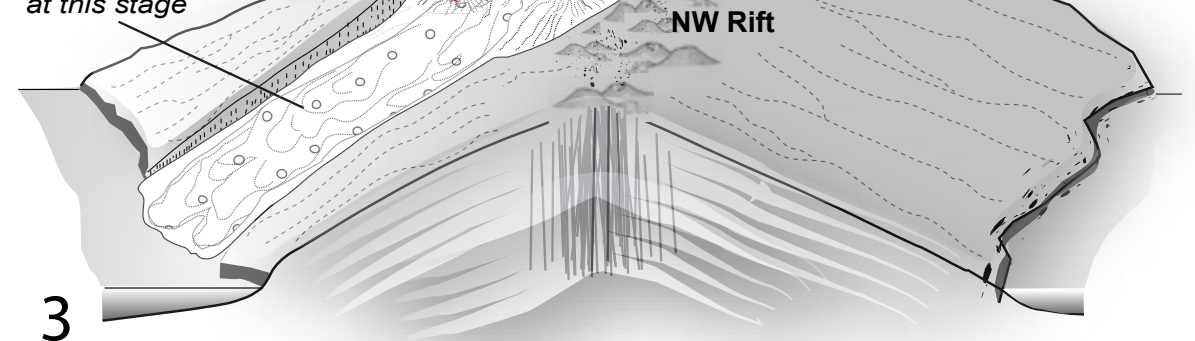

115-30 ka

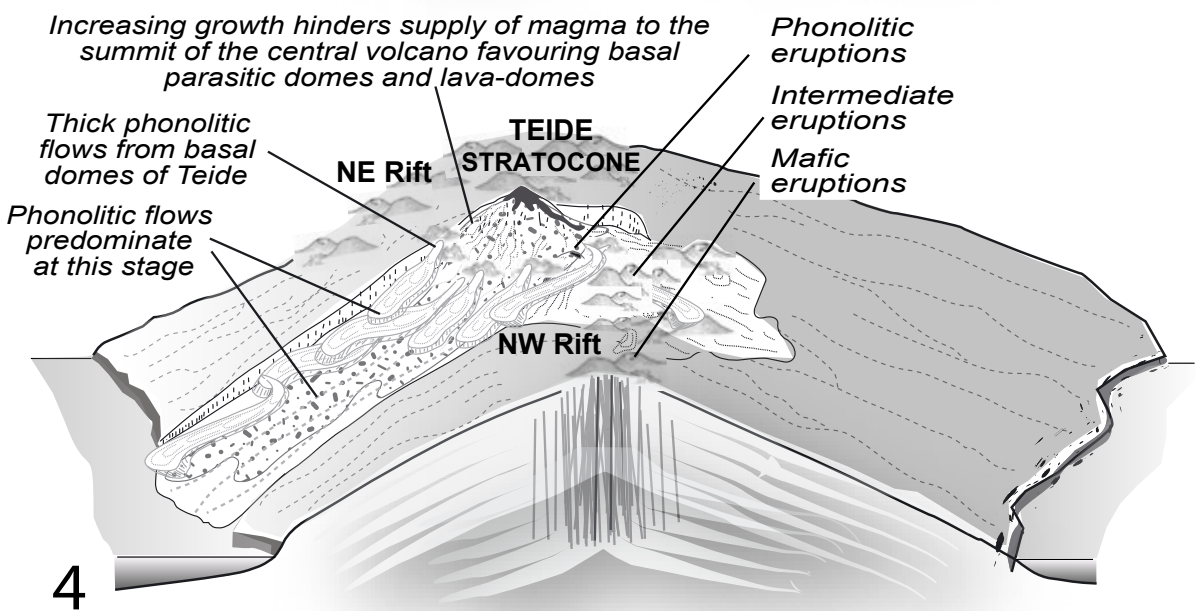

30-0 ka 


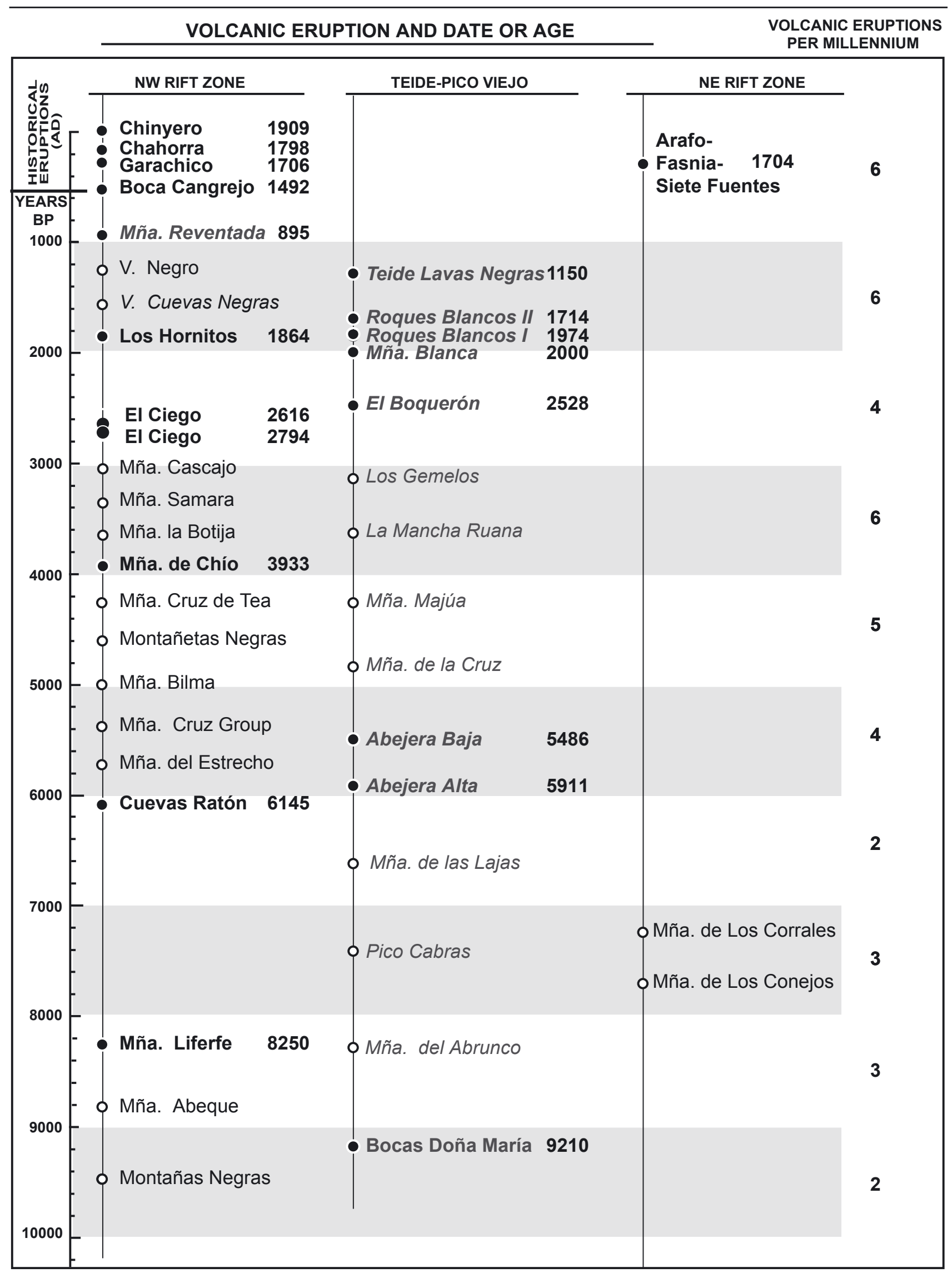



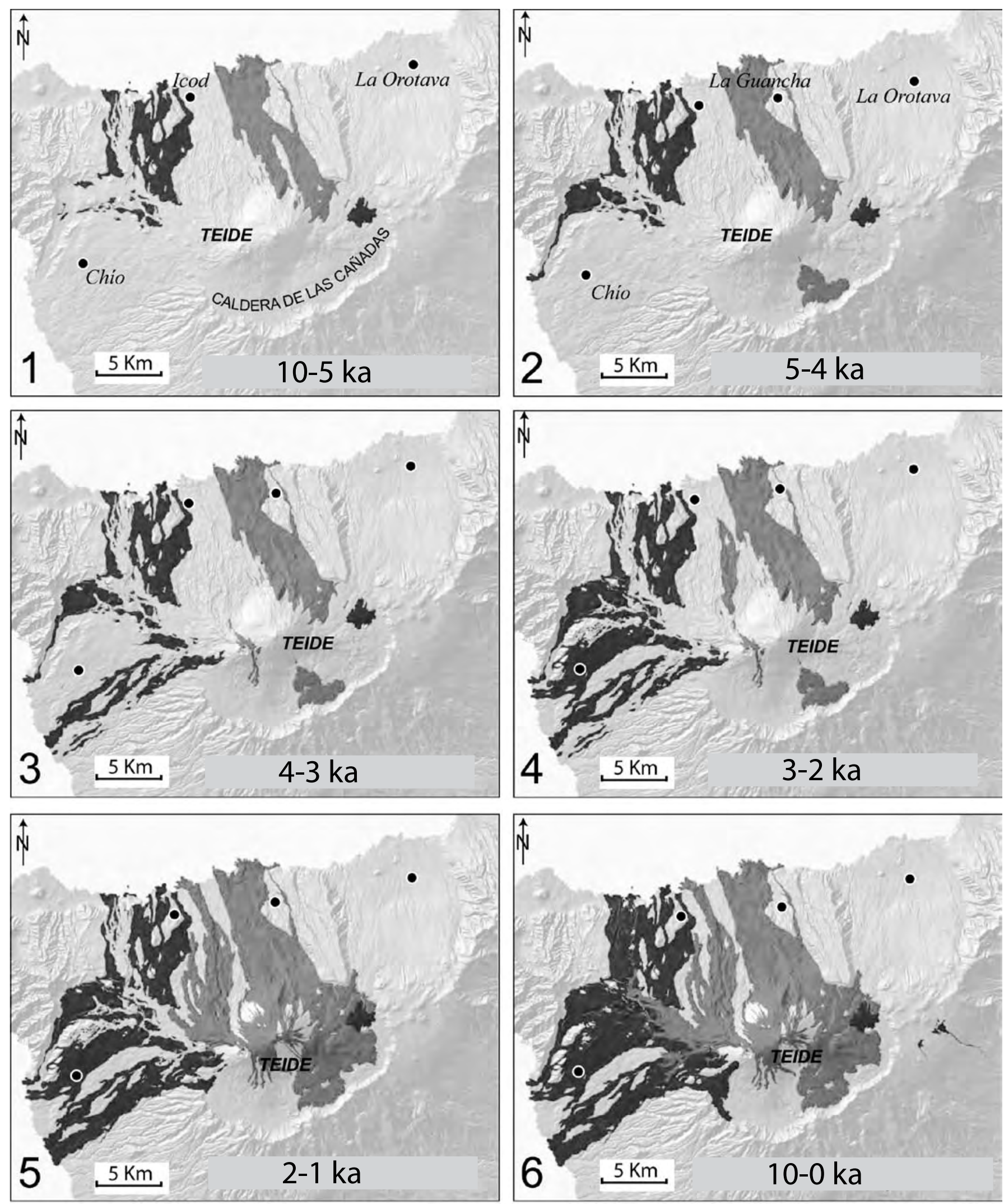

Basaltic and intermediate lavas

Phonolitic lavas 

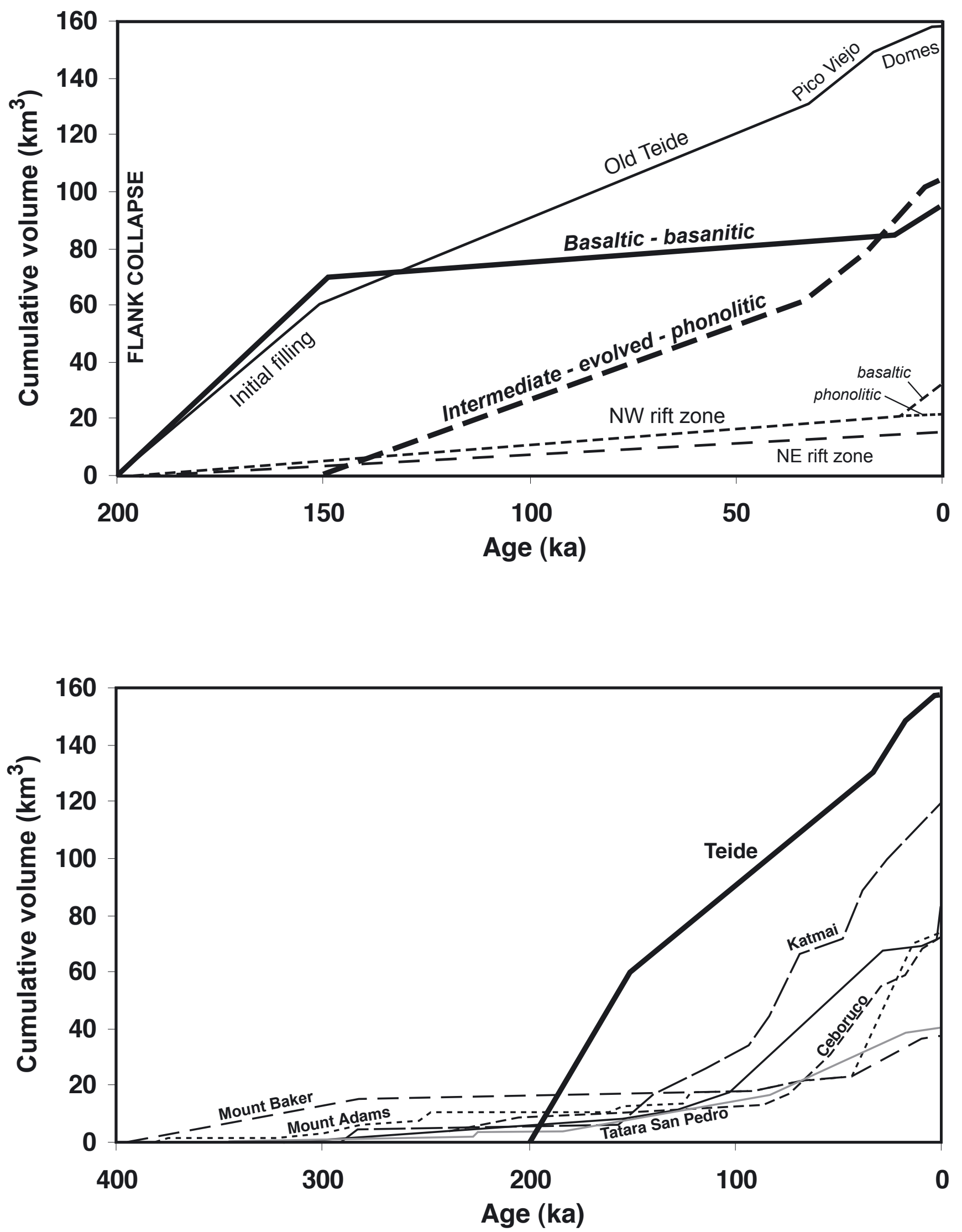




